\title{
Znaczenie i rola Izaaka i Jakuba w historii Izraela według Syracha (Syr 44,22-23)
}

The Significance and Role of Isaac and Jacob in Israel's History According to Sirach (Sir 44:22-23)

\author{
KS. ANDRZEJ PIWOWAR \\ Instytut Nauk Biblijnych, Katolicki Uniwersytet Lubelski Jana Pawła II \\ andpiw@gazeta.pl \\ ORCID: 0000-0001-9316-1791
}

\begin{abstract}
The article is devoted to the analysis of the Greek text of Sir 44:22-23, but it also takes into account the Hebrew version of the praise of Isaac and Jacob. The main aim of the article is to read Sirach's depiction of these two patriarchs in his Praise of the Fathers (Sir 44:1 - 50:24) and the role and significance that he attributes to them in Israel's history. The analysis conducted shows that the Jerusalem sage based his presentation of Isaac and Jacob exclusively on the Book of Genesis, not referring to any theological traditions connected with the patriarchs that were known during the Second Temple period. The principal role played by the two patriarchs in the history of the chosen nation is passing on to the subsequent generation the covenant that God made with Abraham and the promises related to it (Isaac's substantial passivity in this role has to be pointed out). It is this motif that is emphasized in Sir 44:22-23, as a result of which other important events from the patriarchs' lives are completely overlooked, including the justification of Jacob's stealing of Isaac's blessing for his firstborn son.
\end{abstract}

Keywords: Isaac, Jacob, Abraham, the Praise of the Fathers, Sir 44:22-23.

SŁowa KLuczowe: Izaak, Jakub, Abraham, Pochwała Ojców, Syr 44,22-23.

Struktura Księgi Mądrości Syracha jest jedną z najbardziej dyskutowanych i tajemniczych kwestii dotyczących tego dzieła. Wszyscy badacze zgadzają się jednak co do tego, że końcowe rozdziały $(42,14$ - 50,24) wyróżniają się w jego treści, stanowiąc wyraźnie odrębną część Syr ${ }^{1}$. Jest ona spójna zarówno z punktu

Zob. J. Asurmendi, „El elogio de los antepasados (Sir 44-50): haciendo historia...”, Reseña Biblica 41 (2004) 46; A. Bonora, „Siracide”, Libri sapienziali e altri scritti (red. A. Bonora M. Priotto ed altri) (Logos. Coso di Studii Biblici 4; Torino: Elle Di Ci 1997) 89-90.96; tenże, Siracide. Le radici nella tradizione (Leggere oggi la Bibbia 1.17; Brescia: Queriniana 1988) 13-15; R.J. Clifford, The Wisdom Literature (Interpreting Biblical Texts; Nashville: Abingdon 1998) 119-120.124; R.J. Coggins, Sirach (Guides to Apocrypha and Pseudepigrapha; Sheffield: Sheffield Academic Press 1998) 26.78; A.A. Di Lella, „Wisdom of Ben Sira”, The Anchor Bible Dictionary (red. D.N. Freedman) (New York - London - Toronto: Doubleday 1992) VI, 938939; M. Gilbert, Ben Sira. Recueil d'études - Collected Essays (BEThL 264; Leuven - Paris - Walpole: Uitgeverij Peeters 2014) 332-333; J. Marböck, „Il libro del Siracide”, Introduzione all'Antico Testamento (red. E. Zenger) (Brescia: Queriniana 2005) 620-621; A. Minissa- 
widzenia formalnego, jak i merytorycznego. Została poprzedzona poematem sławiącym dzieła Boże w przyrodzie $(42,15-43,33)^{2}$. S. Potocki traktuje obie te jednostki razem, określając je jako „Obszerny poemat wysławiający Mądrość Bożą w dziełach natury $(42,15$ - 43,33) i w dziejach sławnych ludzi $(44,1-50,24)$ "’3, który „wyróżnia się spośród innych perykop księgi objętością, doskonałością

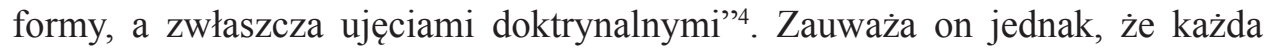
z części tego wielkiego poematu ma własną strukturę (można wyróżnić wstęp i zakończenie każdej z nich $)^{5}$ oraz nieco odmienną formę i tematykę. Obie jednak

le, Siracide (Ecclesiastico) (Nuova Versione della Bibbia 23; Cinisello Balsamo: San Paolo 1989) 201; V. Morla Asensio, Libri sapienziali e altri scritti (Introduzione allo Studio della Bibbia 5; Brescia: Paideia 1997) 186-187; R.E. Murphy, L'albero della vita. Una esplorazione della letteratura sapienziale biblica (Biblioteca Biblica 13; Brescia: Queriniana 22000) 99.107; M.C. Palmisano, Siracide. Introduzione, traduzione e commento (Nuova Versione della Bibbia dai Testi Antichi 34; Cinisello Balsamo: San Paolo 2016) 13-14; M. Phua, „Sirach, Book of”, Dictionary of the Old Testament. Wisdom, Poetry \& Writings (red. T. Longman III - P. Enns) (Downers Grove - Nottingham: IVP Academic - Inter-Varsity Press 2008) 722.724; S. Pinto, I segreti della Sapienza. Introduzione ai Libri sapienziali e poetici (Cinisello Balsamo: San Paolo 2013) 142; J.J. Pudełko, „Dlaczego Adam zamyka Pochwatę Ojców (Syr 44 - 49)”, The Biblical Annals 7/4 (2017) 442; taż, „(Nie)obecność kobiet w Pochwale ojców (Syr 44 - 49)”, 'Niewiaste dzielna kto znajdzie?' (Prz 31,10). Rola kobiet $w$ biblijnej historii zbawienia (red. A. Kubiś - K. Napora) (Analecta Biblica Lublinensia; Lublin: Wydawnictwo KUL 2016) 197; P.W. Skehan - A.A. Di Lella, The Wisdom of Ben Sira (The Anchor Bible 39; New York - London - Toronto: Doubleday 1987) 5; J.S. Synowiec, Mędrcy Izraela, ich pisma i nauka (Kraków: Bratni Zew $\left.{ }^{2} 1997\right)$ 199. G. Sauer uważa, że w Syr można dostrzec rozwój nauczania mędrca, które w Syr 1 - 24 skupia się na postępowaniu jednostki, aby w dalszej części dzieła skupić się na życiu publicznym, czego punktem kulminacyjnym jest Pochwała Ojców (zob. G. Sauer, Studien zu Ben Sira [BZAW 440; Berlin - Boston: de Gruyter 2013] 105).

2 „Nell' economia del libro l'elogio dei padri non è buttato lì a caso. Esso è preceduto dall'elogio di Dio che agisce nel creato $(42,15-43,33)$. Il collegamento con questa parte è evidente: Ben Sirac cerca di scoprire l'azione di Dio nella natura (42-43), poi nella storia (44-50)" (R. Petraglio, Il libro che contamina le mani. Ben Sirac relegge il libro e la storia d'Israele [Teologia IV; Palermo: Edizioni Agustinus 1993] 17). Por. J. Corley, „Sirach 44:1-15 as Introduction to the Praise of the Ancestors", Study in the Book of Ben Sira. Papers of the Third International Conference on the Deuterocanonical Books, Shime'on Centre, Pápa, Hungary, 18-20 May, 2006 (red. G.G. Xeravits - J. Zsengellér) (Supplements to the Journal for the Study of Judaism 127; Leiden - London: Brill 2008) 151-152; P.R. Scalabrini, „La galleria degli antenati (Sir 44-50)”, Libri sapienziali (red. A. Priotto) (Parole di Vita 8; Padova: Messaggero di Sant'Antonio 2015) 315.

3 „Pochwała sławnych ojców stanowi mądrościową interpretację działania Bożego w historii zbawienia. Dlatego próbę syntezy dziejów zbawienia w ujęciu Jezusa Syracha można najogólniej określić jako pochwałę mądrości Bożej w życiu i działalności sławnych bohaterów biblijnych" (W. Pazera, „Pochwała ojców w księdze Jezusa Syracha”, Częstochowskie Studia Teologiczne 14 [1986] 27). Por. Bonora, Siracide, 38.

4 S. Potocki, „Mądrość uczonego w Piśmie (Księga Syracha)”, Mądrość starotestamentowego Izraela (red. S. Potocki i in.) (Wprowadzenie w Myśl i Wezwanie Ksiąg Biblijnych 6; Warszawa: Wydawnictwo ATK 1999) 195.

5 Na temat struktury Syr 44,1 - 50,24 zob.: J. Corley, „A Numerical Structure in Sirach 44:1 50:24”, CBQ 1 (2007) 43-63; A.A. Di Lella, „Ben Sira's Praise of the Ancestors of Old (Sir 44-49): The History of Israel as Parenetic Apologetics", History and identity: how Israel's authors viewed its earlier history (red. N. Calduch-Benages - J. Liesen) (International Society for 
są utrzymane w tonie pochwały ${ }^{6}$. A. Goshen-Gottstein spostrzega, że właściwa część Pochwały Ojców poprzedzona jest (42,15 - 43,33) i zakończona (50,1-24) perykopami o charakterze pochwalnym ${ }^{7}$. Syr 44,1 - 50,24 koncentruje się na opisie życia i działalności najważniejszych postaci z historii Izraela ${ }^{8}$. Syrach rozpoczyna ich prezentację od Henocha $(44,16)$, do którego powraca w 49,149. Swą pieśń pochwalną poświęconą sławnym i wybitnym osobistościom z przeszłości Izraela, kończy długim zachwytem nad arcykapłanem Szymonem, synem Oniasza $(50,1-24)^{10}$. Uważnego czytelnika może jednak zaskoczyć nieobecność po-

the Study of Deuterocanonical and Cognate Literature. International Conference; Berlin - New York: de Gruyter 2006) 153-167; Gilbert, Ben Sira, 336-338; A. Goshen-Gottstein, „Ben Sira's Praise of the Fathers: A Canon-Conscious Reading", Ben Sira's God. Proceedings of the International Ben Sira Conference Durham - Ushaw College 2001 (red. R. Egger-Wenzel) (BZAW 321; Berlin - New York: de Gruyter 2002) 235-267; A. Niccacci, „La Lode dei Padri: Ben Sira tra passato e futuro", Initium sapientiae. Scritti in onore di Franco Festorazzi nel suo $70^{\circ} \mathrm{com}$ pleanno (red. R. Fabris) (Supplementi alla «Rivista Biblica» 36; Bologna: EDB 2000) 199-225; J.L. Ska, „L'éloge des pères dans le Siracide (Si 44-50) et le canon de l'Ancien Testament”, Treasures of wisdom: studies in Ben Sira and the book of Wisdom (FS M. Gilbert) (red. N. Calduch-Benages - J. Vermeylen) (BEThL 143; Leuven: Leuven University Press 1999) 181-193.

6 Zob. Potocki, „Mądrość uczonego w Piśmie (Księga Syracha)”, 195.

7 Zob. Goshen-Gottstein, „Ben Sira's Praise of the Fathers: A Canon-Conscious Reading”, 236. Por. Di Lella, „Ben Sira's Praise of the Ancestors of Old (Sir 44-49): The History of Israel as Parenetic Apologetics", 152.

8 „This unusual journey through the portrait gallery of notables has recently been described as a complete reading of epic history that served as a mythic etiology for Judaism in the period of Second Temple” (J.L. Crenshaw, ,The Book of Sirach. Introduction, Commentary, and Reflections", The New Interpreter's Bible. V: Introduction to Wisdom Literature; Proverbs; Ecclesiastes; Song of Songs; Book of Wisdom; Sirach [Nashville: Abingdon 1997] 631). „By contrast with the earlier wisdom books of the Hebrew Bible (Proverbs, Job, and Qoheleth), the later Wisdom of Ben Sira and the Wisdom of Solomon are clearly characterized by their interest in the biblical account of Israel's ancient history" (Gilbert, Ben Sira, 331). Por. B.L. Mack, Wisdom and the Hebrew Epic. Ben Sira's Hymn in Praise of the Fathers (Chicago - London: The University of Chicago Press 1985); R.A.F. MacKenzie, „Ben Sira as Historian”, Trinification of the World: A Festschrift in Honor of F.E. Crowe (red. T.A. Dunne - J.M. Laport) (Toronto: Regis College Press 1978) 312-327.

9 Zob. Pudełko, „Dlaczego Adam zamyka Pochwałę Ojców (Syr 44 - 49)”, 441-457; Sauer, Studien zu Ben Sira, 107-108.

10 Zob. Corley, „Sirach 44:1-15 as Introduction to the Praise of the Ancestors”, 151; O. Mulder, Simon the High Priest in Sirach 50 (Supplements to the Journal for the Study of Judaism 78; Leiden-Boston: Brill 2003); tenże, „Two Approaches: Simon the High Priest and YHWH God of Israel/God of All in Sirach 50", Ben Sira's God. Proceedings of the International Ben Sira Conference Durham - Ushaw College 2001 (red. O. Kaiser) (BZAW 321; Berlin-New York: de Gruyter 2002) 221-234; A. Piwowar, „Syrach - obrońca prawowitego arcykapłana”, Od Melchizedeka do Jezusa - Arcykaptana (red. D. Dziadosz) (Analecta Biblica Lublinensia 5; Lublin: Wydawnictwo KUL 2010) 93-117. T.R. Lee uważa, że cała Pochwała Ojców jest bardzo długim przygotowaniem do przedstawienia postaci arcykapłana Szymona (zob. T.R. Lee, Studies in the Form of Sir 44 - 50 [SBLDS 75; Atlanta: Scholars Press 1986] 81). Por. Corley, „A Numerical Structure in Sirach 44:1 - 50:24”, 45; Gilbert, Ben Sira, 334; B.G. Gregory, „Abraham as the Jewish Ideal: Exegetical Traditions in Sirach 44:19-21", CBQ 1 (2008) 66. 
śród osób wymienionych w Pochwale Ojców kobiet ${ }^{11}$, Saula $^{12}$, Ezdrasza ${ }^{13}$ i wielu innych ważnych postaci ${ }^{14}$. Ta część Syr nie mówi także nic na temat wygnania do Babilonii ${ }^{15}$. Wśród ważnych dla Izraela i historii zbawienia postaci nie mogło zabraknąć patriarchów (Abrahama, Izaaka i Jakuba), uważanych za protoplastów Narodu Wybranego. Syrach przedstawia ich tuż po Henochu i Noem, którzy otwierają poczet ojców $(44,16-18)$, a przed Mojżeszem $(45,1-5)^{16}$.

W. Pazera zauważa, że Pochwała Ojców, choć nie stanowi podręcznika teologii, to jednak zawiera ,zasadnicze zręby przewodnich, biblijnych idei teologicznych" ${ }^{17}$. Według niego w pochwale każdej osoby podkreślona została wartość monoteizmu. Ponadto w Syr 44,1 - 50,24 mędrzec akcentuje zręby mesjanizmu ${ }^{18}$ oraz profetyzmu. Niektórzy badacze do wymienionych idei teologicznych dodają także wątki eschatologiczne ${ }^{19}$.

11 Zob. N. Calduch-Benages, ,The Absence of Named Women from Ben Sira's Praise of Ancestors", Rewriting Biblical History. Essays on Chronicles and Ben Sira in Honor of Pancratius C. Beentjes (red. J. Corley - H. van Grol) (Deuterocanonical and Cognate Literature Studies 7; Berlin - New York: de Gruyter 2011) 301-318; Coggins, Sirach, 79; Crenshaw, „The Book of Sirach. Introduction, Commentary, and Reflections", 630-631; Petraglio, Il libro che contamina le mani, 18; Pudełko, „(Nie)obecność kobiet w Pochwale ojców (Syr 44 - 49)”, 195-210.

12 Zob. Crenshaw, „The Book of Sirach. Introduction, Commentary, and Reflections”, 633.

13 Zob. Coggins, Sirach, 80; J.L. Crenshaw, Old Testament Wisdom. An Introduction (Louisville: Westminster John Knox Press $\left.{ }^{2} 1998\right)$ 142-143; tenże, „The Book of Sirach. Introduction, Commentary, and Reflections”, 632-633; P. von Höffken, „Warum schwieg Jesus Sirach über Esra?”, ZAW 87 (1975) 184-202; A. Piwowar, „Dlaczego Syrach pominął Ezdrasza w Pochwale Ojców (Syr 44 - 50)?”, The Biblical Annals 1/58 (2011) 105-131; Scalabrini, ,La galleria degli antenati (Sir 44-50)", 317.

14 Zob. Coggins, Sirach, 79-80.

15 Zob. Bonora, „Siracide”, 96; Goshen-Gottstein, „Ben Sira's Praise of the Fathers: A Canon-Conscious Reading”, 238; Scalabrini, „La galleria degli antenati (Sir 44-50)”, 317.

16 „La confessione di fede dell'antico Israele partiva originariamente dal nucleo fondamentale della liberazione dall'Egitto (Es 20,2: Dt 5,6), della conquista della terra promessa (Dt 26,3-10), per allargarsi quindi ai cicli di Abramo, Isacco e Giacobbe (Gn 12-50). Così si costruì lo schema canonico della storia della salvezza. Il discorso sulla creazione (Gn 1-11) fu assunto in un secondo momento, per fornire una prospettiva universale alla vicenda particolare d'Israele, per agganciarla alla storia dei popoli ( $\mathrm{cf}$ Gn $5 ; 10$ !), sorretta e guidata dall'unico Signore" (Minissale, Siracide [Ecclesiastico], 201).

17 Pazera, „Pochwała ojców w księdze Jezusa Syracha”, 291.

18 Por. J. Corley, „Seeds of Messianism in Hebrew Ben Sira and Greek Sirach”, The Septuagint and Messianism (ed. M.A. Knibb) (BEThL CXCV; Leuven - Paris: Leuven University Press Uitgeverij Peeters 2006) 301-312; K.P. Kowalik, „Postać Abrahama w świetle Księgi Syracha”, Przeznaczyteś nas dla Twojej prawdy (4Q 495). Studia dla Dr. Zdzisława J. Kapery w 65. rocznice urodzin (red. W. Chrostowski) (Rozprawy i Studia Biblijne 29; Warszawa: Vocatio 2007) 430-431.

19 Zob. J.D. Martin, „Ben Sira's Hymn to the Fathers: A Messianic Perspective”, Crises and Perspectives (ed. A.S. van der Woude) (Oudtestamentische Studiën 24; Leiden: Brill 1986) 107123; Pazera, „Pochwała ojców w księdze Jezusa Syracha”, 291-293; B.G. Wright III, „Eschatology without a Messiah in the Wisdom of Ben Sira", The Septuagint and Messianism (ed. M.A. Knibb) (BEThL CXCV; Leuven - Paris: Leuven University Press - Uitgeverij Peeters 
Zdaniem R. Petraglio Pochwała Ojców jest ważna z trzech powodów: po pierwsze pozwala poznać, które księgi uważano za kanoniczne w środowisku żydowskim w czasach Syracha i jego wnuka ${ }^{20}$, po wtóre, w jaki sposób mędrcy odczytywali przeszłość Izraela, i po trzecie, Syr 44,1-50,24 pozwala zrozumieć, jak wielką rolę odgrywały księgi święte w życiu wiernych epoki autora ${ }^{21}$. A. Bonora uważa Pochwałę Ojców za najbardziej oryginalną ${ }^{22}$ część dzieła mędrca z Jerozolimy ${ }^{23}$, która posiada cel wychowawczy (pedagogiczny) ukierunkowany ku teraźniejszości ${ }^{24}$. Według opinii tego włoskiego egzegety najważniejszą ideą całej tej części dzieła mędrca z Jerozolimy jest przymierze ${ }^{25}$. G. Sauer uważa, że głównym celem Syr 44,1 - 50,24 nie było ukazanie dzieł wybitnych postaci

2006) 313-323. Por. S. Potocki, „Księgi mądrościowe”, Wstęp do Starego Testamentu (red. S. Łach) (Wstęp do Pisma Świętego 2; Poznań - Warszawa: Pallottinum 1973) 735-736.

20 Por. Goshen-Gottstein, „Ben Sira's Praise of the Fathers: A Canon-Conscious Reading”, 240260; Scalabrini, „La galleria degli antenati (Sir 44-50)”, 315-316; Ska, „L'éloge des pères dans le Siracide (Si 44-50) et le canon de l'Ancien Testament", 182-193.

21 Zob. Petraglio, Il libro che contamina le mani, 20. Por. B.G. Wrigdht III, „The Use and Interpretation of Biblical Tradition in Ben Sira's Praise of the Ancestors", Study in the Book of Ben Sira. Papers of the Third International Conference on the Deuterocanonical Books, Shime'on Centre, Pápa, Hungary, 18-20 May, 2006 (red. G.G. Xeravits - J. Zsengellér) (Supplements to the Journal for the Study of Judaism 127; Leiden - London: Brill 2008) 183-207.

22 R.N. Whybray określa Syracha jako pierwszego z żydowskich pisarzy mądrościowych, który w swym dziele zainteresował się historią (zob. R.N. Whybray, „Ben Sira and History”, Treasures of wisdom: studies in Ben Sira and the book of Wisdom [FS M. Gilbert] [red. N. Calduch-Benages - J. Vermeylen] [BEThL 143; Leuven: Leuven University Press 1999] 137). „History for Ben Sira is not an eccentric appendage to his teaching; it is part and parcel of his conception of "wisdom theology"' (tamże, 137). R.J. Clifford w następujący sposób wyjaśnia oryginalność Syr 44,1-50,24: „The traditional realm of wisdom literature was personal and familiar. It was not concerned with national history, but Ben Sira extended the range of wisdom's purview" (Clifford, The Wisdom Literature, 129). ,[...] Ben Syrach otworzył nowy etap w teologii izraelskiej. Przyczynił się do zintegrowania tradycji biblijnej i świeckiej tradycji mądrościowej” (Kowalik, „Postać Abrahama w świetle Księgi Syracha”, 424). R.E. Murphy nowość Pochwały Ojców dostrzega w fakcie, że wychwalani są ludzie a nie Bóg (zob. Murphy, L'albero della vita, 107; por. Coggins, Sirach, 78-79; Goshen-Gottstein, „Ben Sira's Praise of the Fathers: A CanonConscious Reading”, 238-239). Por. Asurmendi, „El elogio de los antepasados (Sir 44-50): haciendo historia...”, 45; Coggins, Sirach, 79; Corley, „Sirach 44:1-15 as Introduction to the Praise of the Ancestors", 152; M. Gilbert, Le cinq livres des Sages (Lire la Bible 129; Paris: Cerf 2003) 218-219; Morla Asensio, Libri sapienziali e altri scritti, 196; Pazera, „Pochwała ojców w księdze Jezusa Syracha", 271.

23 „Qui [Syr 44 - 50 - przyp. autora] è il «climax» dell'opera, cui tendono i capitoli precedenti. La «laus patrum» è anche la sezione più originale di tutta l'opera. Si tratta di una rilettura del passato nel genere midrash haggadico” (Bonora, „Siracide”, 96). Por. Niccacci, „La Lode dei Padri: Ben Sira tra passato e futuro”, 199-225; Scalabrini, „La galleria degli antenati (Sir 44-50)”, 315.

24 Por. Goshen-Gottstein, „Ben Sira's Praise of the Fathers: A Canon-Conscious Reading”, 236237; Pazera, „Pochwała ojców w księdze Jezusa Syracha”, 294-306.

25 „Il tema dell'alleanza percorre tutta la visione siracidea della storia: nei cc. $44-49$ il termine berît ricorre 11 volte. Il concetto di alleanza di Ben Sira si avvicina a quello della tradizione sacerdotale: l'alleanza è una benevola e libera disposizione della divina Provvidenza, una promessa fatta da Dio” (Bonora, „Siracide”, 96). Por. J. Marböck, „Die «Geschichte Israels» als 'Bundesgeschichte' nach dem Sirachbuch”, Der neue Bund im alten. Studien zur Bundestheologie 
z przeszłości Izraela, ale wierności Boga narodowi, który On wybrał ${ }^{26}$. Wielu badaczy Syr twierdzi, że Pochwała Ojców ma charakter apologetyczny ${ }^{27}$, a nawet eschatologiczny ${ }^{28}$.

Celem niniejszego artykułu jest przedstawienie Syrachowego ujęcia postaci patriarchów: Izaaka i Jakuba ${ }^{29}$. Najpierw zostaną omówione kwestie literackie Syr 44,19-23. Następnie zostanie dokonana analiza egzegetyczno-teologiczna tegoż tekstu, aby ukazać, w jaki sposób mędrzec ich przedstawił oraz jaką rolę przypisał im w historii narodu wybranego.

\section{Tekst Syr $44,22-23$}

W analizie postaci Izaaka i Jakuba w Syrachowej Pochwale Ojców, której poświęcony jest niniejszy artykuł, oprzemy się przede wszystkim na tekście greckim Syr 44,22-23. Będzie on punktem wyjścia dla podjętych badań, ponieważ właśnie on został uznany za kanoniczny. Nie ograniczymy się jednak wyłącznie do wersji greckiej, ale dokonamy również konfrontacji tłumaczenia wnuka z pierwowzorem hebrajskim.

Tłumaczenie Syr 44,22-23 na podstawie wydania krytycznego tekstu greckiego tej księgi J. Zieglera ${ }^{30}$ (zachowana została numeracja wersetów zgodna z wydaniem Biblii Tysiąclecia, tak aby ułatwić czytelnikowi śledzenie tekstu ${ }^{31}$ ):

der beiden Testamente (red. E. Zenger) (Quaestiones Disputate 146; Freiburg - Basel - Wien: Herder 1993) 177-197; Scalabrini, ,La galleria degli antenati (Sir 44-50)”, 316.

26 Zob. Sauer, Studien zu Ben Sira, 107.

27 Zob. Di Lella, „Ben Sira's Praise of the Ancestors of Old (Sir 44-49): The History of Israel as Parenetic Apologetics”, 153-167; Gilbert, Ben Sira, 344; Whybray, „Ben Sira and History”, 138.

Zob. E. Jansen, Das Gottesvolk und seine Geschichte. Geschichtsbild und Selbstverständnis im palästinensischen Schrifttum von Jesus Sirach bis Jehuda ha-Nasi (Neukirchen: Neukirchener Verlag 1971) 16.

29 Postaci Abrahama w Pochwale Ojców został poświęcony artykuł (A. Piwowar, „Postać Abrachama w Pochwale Ojców [Syr 44,19-21]”), który ukaże się w czwartym numerze Collectanea Theologica z $2018 \mathrm{r}$.

30 Zob. J. Ziegler, Sapientia Iesu Filii Sirach (Septuaginta. Vetus Testamentum Graecum Auctoritate Academiae Scientiarum Gotteingensis editum XII/2; Göttingen: Vandenhoeck\&Ruprecht $\left.{ }^{2} 1980\right)$ 334-335. Por. A. Rahlfs (red.), Septuaginta. Id est Vetus Testamentum graece iuxta LXX interpretes II (Stuttgart: Deutsche Bibelgesellschaft 1979) 456.

31 W krytycznym wydaniu Syr pod redakcją J. Zieglera Syr 44,22 liczy trzy stychy (a, b, c), a Syr 44,23 zawiera ich siedem (a, b, c, d, e, f, g), podczas gdy w BT pierwszy z nich zawiera dwa stychy, a drugi sześć (por. P.C. Beentjes, „Ben Sira 44:19-23 - The Patriarchs Text, Tradition, Theology", Studies in the Book of Ben Sira. Papers of the Third International Conference on the Deuterocanonical Books, Shime’on Centre, Pápa, Hungary, 18-20 May, 2006 [red. G.G. Xeravits - J. Zsengellér] [Supplements to the Journal for the Study of Judaism 127; Leiden - London: Brill 2008] 210-212; F.V. Reiterer, Zählsynopse zum Buch Ben Sira [Fontes et Subsidia ad Bibliam Pertinentes 1; Berlin - New York: de Gruyter 2003] 220-223). Należy zauważyć, że dwa ostatnie stychy Syr 44,23, tj. f-g, odnoszą się nie do Jakuba, lecz Mojżesza, dlatego też w Biblii 
22 I w Izaaku ustalit w ten sam sposób

z powodu Abrahama ojca jego.

23 Blogosławieństwo wszystkich ludzi i przymierze

złożyt na głowie Jakuba,

rozpoznat go w swoich błogosławieństwach

i dat mu w dziedzictwo;

rozdzielit dzialy jego,

pośród pokoleń podzielit dwanaście ${ }^{32}$.

Tekst hebrajski Syr 44,22-23 zachował się w manuskrypcie B odnalezionym w genizie synagogi kairskiej ${ }^{33}$. Większość wydań tej wersji tekstu Syr zalicza do 44,22 trzy stychy (również w. 23a), zaś do 44,23 pięć stychów (poczynając od w. 23b).

Tysiąclecia zostały włączone do Syr 45 (por. Crenshaw, „The Book of Sirach. Introduction, Commentary, and Reflections", 839; Minissale, Siracide [Ecclesiastico], 213; C. Mopsik, La Sagesse de ben Sira [Les Dix Paroles; Paris: Verdier 2003] 281; Palmisano, Siracide, 422). Niektórzy egzegeci potwierdzają przynależność tych stychów do pochwały Mojżesza, jednak nie włączają ich do Syr 45, lecz pozostawiają w Syr 44,23. Np. N. Peters pisze: „23 VI - VII [27]. Die zwei Stichen sind natürlich zu 45,1 zu ziehen und gehen auf Moses" (N. Peters, Der jüngst wiederaufgefundene Hebräische Text des Buches Ecclesiasticus [Freiburg im Breisgau: Herdersche Verlagschandlung 1902] 234; Por. V. Morla, Los manuscritos hebreos de Ben Sira. Traducción y notas [Asociación Bíblica Española 59; Estella: Editorial Verbo Divino 2012] 287-288; Petraglio, Il libro che contamina le mani, 101; N. Peters, Das Buch Jesus Sirach oder Ecclesiasticus [Exegetisches Handbuch zum Alten Testament 25; Münster: Aschendorff 1913] 382; Skehan - Di Lella, The Wisdom of Ben Sira, 506.509; B.M. Zapff, Jesus Sirach 25 - 51 [Die Neue Echter Bibel. Altes Testament: Würzburg: Echter 2010] 324). R. Smend uważa jednak, że Syr 44,23fg nie odnoszą się do Mojżesza, lecz do Józefa - syna Jakuba (zob. R. Smend, Die Weisheit des Jesus Sirach erklärt [Berlin: Verlag von Georg Reimer 1906] 426). Opinii tej sprzeciwia się wielu egzegetów, np. B.M. Zapff: „Auffällig ist, dass Joseph und seine Taten unerwähnt bleiben (vgl. jedoch 49 ${ }^{15}$ )" (Zapff, Jesus Sirach 25 - 51, 324). Por. także Crenshaw, „The Book of Sirach. Introduction, Commentary, and Reflections”, 842; G. Sauer, Jesus Sirach/ Ben Sira (Das Alte Testament Deutsch. Apokryphen 1; Göttingen: Vandenhoeck \& Ruprecht 2000) 306.

32 Thumaczenie tekstu greckiego Syr 44,19-23 por. W. Kraus - M. Karrer (red.), Septuaginta Deutsch. Das griechische Alte Testament in deutscher Übersetzung (Stuttgart: Deutsche Bibelgesel1schaft 2009) 1152; Księgi greckie. Przektad interlinearny z kodami gramatycznymi i indeksem form podstawowych (tłum. M. Wojciechowski) (Prymasowska Seria Biblijna; Warszawa: Vocatio 2008) 679; Palmisano, Siracide, 420-421; A. Pietersma - B.G. Wright (red.), A New English Translation of the Septuagint. And the Other Greek Translations Traditionally Included under that Title (New York - Oxford: Oxford University Press, 2007) 756; Septuaginta czyli Biblia Starego Testamentu wraz z ksiegami deuterokanonicznymi i apokryfami (tłum. R. Popowski) (Prymasowska Seria Biblijna; Warszawa: Vocatio 2013) 1258.

33 Zob. P.C. Beentjes, The Book of Ben Sira in Hebrew. A Text Edition of all Extant Hebrew Manuscripts and a Synopsis of all Parallel Hebrew Ben Sira Texts (Supplements to Vetus Testamentum LXVIII; Leiden - New York - Köln: E.J. Brill, 1997) 78-79; P. Boccaccio G. Bernardi, Ecclesiasticus. Textus hebraeus secundum fragmenta reperta (Roma: Editrice PIB 1986) 31; The Book of Ben Sira. Text, Concordance and an Analysis of the Vocabula$r y$ (The Historical Dictionary of the Hebrew Language; Jerusalem: The Academy of the Hebrew Language and the Shrine of the Book 1973) 54-55; I. Lévi, The Hebrew Text of 
22 Również dla Izaaka ustanowit syna

z powodu Abrahama ojca jego,

23 przymierze każdego poprzedniego dat mu.

(23) I błogosławieństwo opart na głowie Izraela

i umocnit go w błogosławieństwie

$i$ dat mu dziedzictwo jego

i umocnit go w pokoleniach,

żeby podzielić dwanaście $e^{34}$.

Porównując hebrajski oryginał z jego greckim tłumaczeniem, należy stwierdzić, że obie wersje Syr 44,22-23 są zbieżne ze sobą, tzn. nie ma pomiędzy nimi większych i ważnych z punktu widzenia teologicznego różnic. Należy jednak zwrócić uwagę, że w Syr 44,22a tekst hebrajski zawarty na marginesie proponuje słowo בן (,,syn”) zamiast (,tak”, „w ten sam sposób”). Ponadto 44,23b tekst hebrajski zawiera imię Izrael (lekcja ta potwierdzona jest przez wersję syryjską $a^{35}$ ), podczas gdy wersja grecka mówi o Jakubie ${ }^{36}$. Tekst oryginalny 44,23c stwierdza, że Bóg umocnił Izraela w błogosławieństwie (tekst na marginesie manuskryptu mówi o przyznaniu mu tytułu pierworodnego: יוכנהו בבכורה; również tę lekcję potwierdza tekst syryjski ${ }^{37}$ ), zaś wersja grecka wyraża myśl, że On rozpoznał go w błogosławieństwie ${ }^{38}$. W 44,23e tekst hebrajski mówi o umocnieniu Izraela, a tłuma-

the Book of Ecclesiasticus (Semmitic Study Series; Leiden: Brill 1904) 59-60. Zob. http:// bensira.org/navigator.php?Manuscript $=\mathrm{B} \&$ PageNum $=27$ [dostęp: 20.05.2018]. Por. Peters, Das Buch Jesus Sirach oder Ecclesiasticus, 380-382; tenże, Der jüngst wiederaufgefundene Hebräische Text des Buches Ecclesiasticus, 231-234; Smend, Die Weisheit des Jesus Sirach erklärt, 423-426. Por. Beentjes, „Ben Sira 44:19-23 - The Patriarchs Text, Tradition, Theology", 209-214.

34 Thumaczenie tekstu hebrajskiego zob. Mopsik, La Sagesse de ben Sira, 280-281; Morla, Los manuscritos hebreos de Ben Sira. Traducción y notas, 286-287; Palmisano, Siracide, 420-421; http://bensira.org/navigator.php?Manuscript=B\&PageNum=27 [dostęp: 20.05.2018]. Por. Peters, Hebräische Text des Buches Ecclesiasticus, 408; Petraglio, Il libro che contamina le mani, 86; Sauer, Jesus Sirach/Ben Sira, 303-304; Skehan - Di Lella, The Wisdom of Ben Sira, 504; R. Smend, Die Weisheit des Jesus Sirach hebräisch und deutsch (Berlin: Verlag von Georg Reimer 1906) 79; J. Vella, „Eclesiastico”, La Sagrada Escritura. Texto y comentario. Antiguo Testamento. V: Eclesiástico, Isaía, Jeremías, Ezequiel (red. A.T. Fernández) (Madrid: La Editorial Catolica, S.A. 1970) 189; Zapff, Jesus Sirach 25 - 51, 323-324. Na temat możliwych przyczyn różnic w tłumaczeniu tekstu hebrajskiego Syr 44,19-21 zob. Petraglio, Il libro che contamina le mani, 72-74; F.V. Reiterer, »Urtext« und Übersetzungen. Sprachstudie über Sir 44,16 - 45,26 als Beitrag zur Siraforschung (Münchener Universitätsschriften 12; St. Ottilien: EOS Verlag St. Ottilien 1980) 108-117.

35 Zob. N. Calduch-Benages - J. Ferrer - J. Liesen, La Sabiduria del escriba. Wisdom of the Scribe (Bibioteca Midrásica 26; Estella: Editorial Verbo Divino 2003) 244.

36 Zob. Reiterer, »Urtext« und Übersetzungen, 112.

37 Zob. Calduch-Benages - Ferrer - Liesen, La Sabiduría del escriba. Wisdom of the Scribe, 244.

38 Zob. Morla, Los manuscritos hebreos de Ben Sira, 287; Reiterer, »Urtext« und Übersetzungen, 113-114. 
czenie wnuka Syracha o nakazie ${ }^{39}$, jednak obie wersje odnoszą tę czynność do podziału na dwanaście części stosownie do dwunastu pokoleń.

\section{Izaak (Syr 44,22)}

Syrach, po przedstawieniu w Pochwale Ojców Abrahama - ojca narodu żydowskiego - i zapowiedzi odnoszących się do jego potomstwa (Syr 44,19-21), prezentuje zgodnie z przekazem Księgi Rodzaju postać jego syna - Izaaka. Powodem, dla którego mędrzec z Jerozolimy poświęcił synowi Abrahama zaledwie dwa stychy (wersja grecka), może być fakt, że w historii patriarchów nie odegrał on znaczącej rolii ${ }^{40}$. Po lekturze rozdziałów poświęconych jego osobie (Rdz $21-35^{41}$, choć należy podkreślić, że główne narracje o nim znajdują się w Rdz $21-28^{42}$, a zwłaszcza w Rdz $26^{43}$ ) dochodzimy do wniosku, że jego dzieje w dużej mierze są powtórzeniem wydarzeń z życia jego ojca (por. Rdz 26 i Rdz 12 i $20^{44}$ ) oraz że nie zawsze odgrywa on w nich główną rolę, ponieważ od narodzin Jakuba Izaak przechodzi jakby na drugi plan historii rodu Abrahama ${ }^{45}$. Nie dziwi wobec tego, że Syrach nie poświęcił mu zbyt wiele miejsca w Pochwale Ojców.

„Stary Testament ukazał Izaaka przede wszystkim jako spadkobiercę obietnic danych przez Boga Abrahamowi, jako syna Obietnicy, ojca 'domu Izaaka', tj. królestwa północy (Izraela), człowieka poddanego woli Bożej”46.

Cechą charakterystyczną Izaaka jest bierność, czego najlepszym wyrazem jest fakt, że rodzice wybrali mu żonę (Rebekę), gdy miał on już 40 lat (Rdz 24) ${ }^{47}$.

39 Zob. Morla, Los manuscritos hebreos de Ben Sira, 287; Reiterer, »Urtext« und Übersetzungen, 115-117.

40 Zob. Palmisano, Siracide, 420; Petraglio, Il libro che contamina le mani, 78. Zdaniem N. Petersa, objętość tekstu poświęcona Izaakowi w Pochwale Ojców wynika z faktu, że był on postacią całkowicie bierną (zob. Peters, Das Buch Jesus Sirach oder Ecclesiasticus, 381).

41 Zob. R. Martin-Achard, „Isaac”, The Anchor Bible Dictionary (ed. D.N. Freedman) (New York - London - Toronto: Doubleday 1992) III, 463-464.

42 Zob. A.B. Lutter - S.L. Klouda, „Isaac”, Dictionary of the Old Testament: Pentateuch (ed. T.D. Alexander - D.W. Baker) (Illinois - Leicester: InterVarsity Press 2003) 445; Petraglio, Il libro che contamina le mani, 75.

43 Zob. Petraglio, Il libro che contamina le mani, 76-78; S. Wypych, Pięcioksiag (Wprowadzenie w Myśl i Wezwanie Ksiąg Biblijnych 1; Warszawa: Akademia Teologii Katolickiej 1987) 75.

44 Zob. Martin-Achard, „Isaac”, 464.

45 Zob. J. Barton, „Izaak”, Stownik wiedzy biblijnej (red. B.M. Metzger - M.D. Coogan) (Warszawa: Vocatio 1996) 244-245; Lutter - Klouda, „Isaac”, 446; Martin-Achard, „Isaac”, 464.

46 P.C. Bosak, Stownik - konkordancja osób Nowego Testamentu (Poznań: W drodze 1991) 123; Palmisano, Siracide, 420.

47 Zob. Lutter - Klouda, „Isaac”, 446; Petraglio, Il libro che contamina le mani, 74-75. 
„Izaak pozostał człowiekiem pasywnym, naiwnym i niewinnym - nieświadomym intencji, jakie żywili wobec niego inni. Nie znał planu Bożego dla swoich synów Jakuba i Ezawa (Rdz $25,23)$ ani nie domyślił się zmowy Rebeki i Jakuba w celu wydostania od niego błogosławieństwa należnego Ezawowi (Rdz 27)"48.

Wydaje się, że głównym zadaniem, jakie zostało przypisane Izaakowi w Księdze Rodzaju i historii Izraela, to bycie pomostem łączącym Abrahama z Jakubem i przekazanie temu ostatniemu obietnic, które otrzymał jego dziadek ${ }^{49}$. Dopiero późniejsze tradycje judaistyczna i chrześcijańska nadały mu o wiele większe znaczenie i przypisały ważniejszą rolę w historii zbawienia niż $R d z^{50}$. Należy jednak podkreślić, że pod wieloma względami Izaak wyróżniał się spośród pozostałych patriarchów, między innymi tym, że jako jedyny żył w związku monogamicznym (posiadał tylko jedną żonę), a całe swoje życie spędził wyłącznie w Kanaanie ${ }^{51}$.

Powyższe stwierdzenia dotyczące Izaaka, a bazujące na Rdz, w pełni potwier-

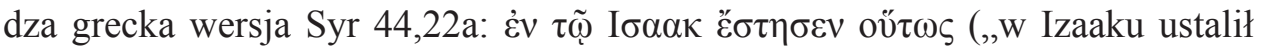
w ten sam sposób"). Tekst tego stychu zawiera dwie trudności. Obie związane są z formą czasownikową ह̌ $\sigma \tau \eta \sigma \varepsilon v$. Po pierwsze rodzi się pytanie: kto jest podmiotem działania? Na kogo wskazuje trzecia osoba liczby pojedynczej trybu oznajmującego aorystu strony czynnej? Aby odpowiedzieć na to pytanie, należy odwołać się do kontekstu poprzedzającego pierwszy stych Syr 44,22. W Syr 44,19-21 (tekst bezpośrednio poprzedzający analizowany przez nas werset) mędrzec wygłosił pochwałę Abrahama - ojca Izaaka. Po ogólnym przedstawieniu go $(44,19)$ skupił się najpierw na jego doskonałości moralno-religijnej $(44,20)$, a następnie przedstawił obietnice, które otrzymał on od Boga (Syr 44,21). W wersecie 20 podmiotem jest Abraham. Wyraźnie wskazuje na to zaimek względny ő na początku pierwszego stychu tego wersetu, który odnosi się do patriarchy

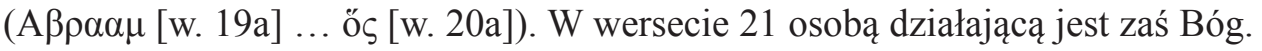

48 J. Unterman, „Izaak”, Encyklopedia biblijna (red. P.J. Achtemeier) (Warszawa: Vocatio - Adam: 1999) 417.

49 Zob. Lutter - Klouda, „Isaac”, 446-447. „[...] an overall assessment of Isaac reveals that he is actually a surprisingly complex figure. Possessing certain noteworthy strengths, he also manifests significant weaknesses. And even if he is not center stage in biblical text nearly as much as Abraham or Jacob, Isaac is the most prominent 'supporting actor' in the patriarchal narratives $[\ldots]$ The Isaac stories function as a hinge in the larger narrative structure of Genesis, looking retrospectively to Abraham and prospectively to Jacob. Isaac plays a significant role in advancing the theme of patriarchal blessing, providing the necessary genealogical link between Abraham and Israel" (tamże, 447). ,It is no less true, however, that the patriarch Isaac is, in the biblical narrative, the indispensable link that connects the history of Abraham to that of Jacob. This is the function that gives him his primary significance” (Martin-Achard, „Isaac”, 463).

50 Zob. Martin-Achard, „Isaac”, 469-470.

51 Zob. Lutter-Klouda, „Isaac”, 446. 
To On składa Abrahamowi obietnice odnoszące się do jego potomstwa ${ }^{52}$. Na tej

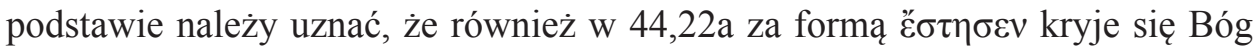
jako ten, który dokonał działania wyrażonego tym słowem. Podkreśla to również drugi stych wersetu 22, który stwierdza, że Abraham był powodem tego, co zostało wyrażone w pierwszej części niniejszego wersetu. Nie może więc być on podmiotem ह̌ $\sigma \tau\rceil \sigma \varepsilon v$. Za uznaniem Boga za podmiot analizowanej przez nas formy czasownikowej przemawia również argument, który można odnieść do logiki przesłania tekstu. W 44,21 Abraham otrzymał od Pana obietnice dotyczące jego potomstwa, werset następny $(44,22)$ rozpoczyna opis realizacji tych zapowiedzi. Skoro więc Bóg przyrzekł ojcu Izraela liczne potomstwo, to również On zaczyna realizować to, co obiecał.

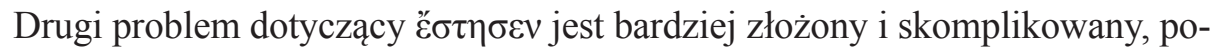
nieważ odnosi się do znaczenia tej formy czasownikowej. Jest to trzecia osoba liczby pojedynczej trybu oznajmującego aorystu strony czynnej ǐ $\tau \tau \eta \mu$. Czasownik ten może posiadać znaczenie zarówno przechodnie, jak i nieprzechodnie. W aoryście strony czynnej oba znaczenia posiadają odmienne formy morfologiczne: aoryst sygmatyczny ( $\check{\sigma} \sigma \eta \sigma \alpha)$ jest przechodni („stawiać”, „utwierdzać”,

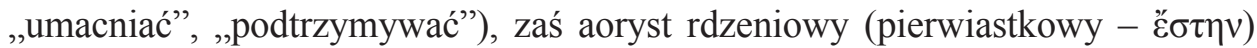
jest nieprzechodni (,stanąć”, „stawać”, „stać mocno”) ${ }^{53}$. Analizowana przez nas forma jest aorystem sygmatycznym i powinna posiadać znaczenie przechodnie, ale nie łączy się z żadnym dopełnieniem bliższym, co może z kolei sugerować, że jest użyta jako nieprzechodnia. Najprościej byłoby rozwiązać powyższą trudność, odwołując się do tekstu oryginalnego, którego wersja grecka Syr 44,22a jest dosłownym tłumaczeniem. Jednak to nie wyjaśnia trudności zawartych w tekście greckim.

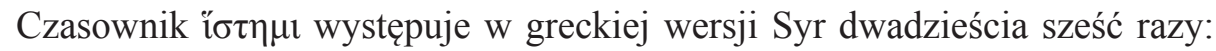
trzynaście razy z dopełnieniem bliższym (znaczenie przechodnie) ${ }^{54}$ i tyleż samo razy bez niego (znaczenie nieprzechodnie) ${ }^{55}$. W aoryście strony czynnej czasownik ten występuje szesnaście razy: w formie nieprzechodniej sześć razy ${ }^{56}$, zaś przechodniej dziesięć razy ${ }^{57}$. Należy jednak zwrócić uwagę, że w formie przechodniej osiem na dziesięć razy łączy się z dopełnieniem bliższym, jedynie w 44,21a i 22a nie posiada go (F.R. Reiterer użycie w obu tych tekstach

52 Zob. Palmisano, Siracide, 418.

53 Zob. A. Piwowar, Greka Nowego Testamentu. Gramatyka (Biblioteka 'Verbum Vitae' 1; Kielce: Verbum 2010) 451. Odnośnie do znaczenia poszczególnych form zob. J. Lust - E. Eynikel K. Hauspie, A Greek-English Lexicon of the Septuagint (Stuttgart: Deutsche Bibelgesellschaft 1992) I, 216; T. Muraoka, A Greek-English Lexicon of the Septuagint (Louvain - Paris - Walpole: Peeters 2009) 343-344.

$54 \quad$ Zob. Syr 12,$12 ; 14,25 ; 17,12 ; 27,26 ; 37,13 ; 44,20 ; 45,7.23 .24 ; 46,3 ; 47,9.13 ; 49,13$.

55 Zob. Syr 6,$34 ; 11,20 ; 12,12 ; 21,23.25 ; 37,9 ; 39,17 ; 40,12 ; 43,10 ; 44,12.21 .22 ; 50,12$.

56 Zob. Syr 6,34; 11,20; 12,12;39,17; 44,12 i 46,3.

57 Zob. Syr 12,$12 ; 17,12 ; 37,13 ; 44,20 ; 44,21.22 ; 45,7 ; 47,9.13$ i 49,13. 


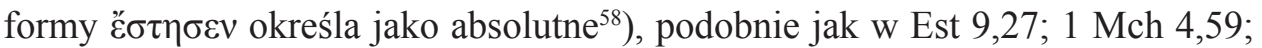
Hi 20,19 i Dn (wersja Teodocjona) 3,2.7. Na tej podstawie w obu tych tekstach

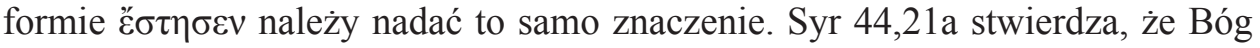

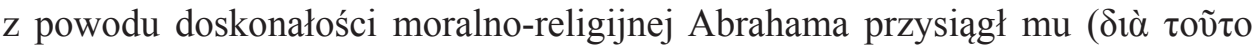

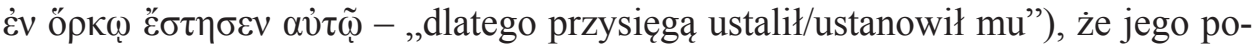
tomstwo będzie pośrednikiem błogosławieństwa Bożego dla innych narodów, że rozmnoży je i wywyższy oraz że posiądzie ziemię aż po krańce świata $(44,21$ b-g). W stychu tym brakuje dopełnienia bliższego, ale w jego miejscu poja-

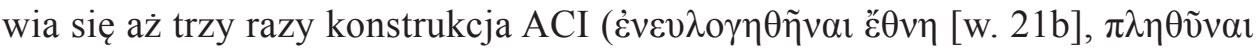

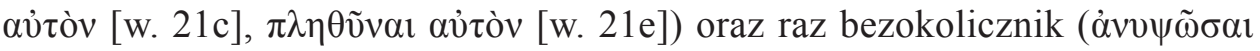

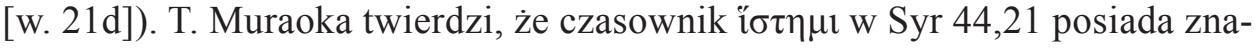
czenie przechodnie ${ }^{59}$. W bardzo podobny sposób (brak dopełnienia bliższego)

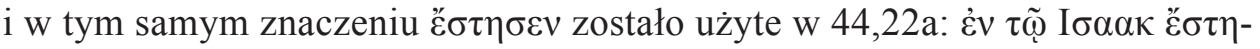
$\sigma \varepsilon v$ oṽ $\omega \varsigma$ (,w Izaaku ustalił w ten sam sposób" $\left.{ }^{60}\right)$. W 44,20c analizowana przez nas forma czasownika $i \sigma \tau \eta \mu$ pojawia się w formie przechodniej z do-

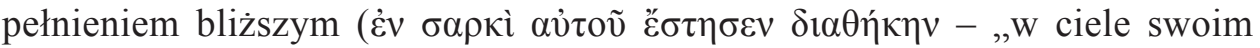
ustanowił przymierze"). Być może wnuk Syracha, tłumacząc tekst oryginalny na język grecki, pominął dopełnienie bliższe (zob. poniżej trudności związane

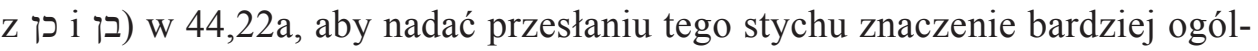
ne i mniej precyzyjne, i w ten sposób nie wskazać tylko jednego przedmiotu, ale poszerzyć znaczenie tego stychu poprzez brak dopełnienia bliższego, które dokładnie określałoby, o co chodzi i co Bóg ustanowił dla Izaaka. Gdyby bowiem dodał do ह̌ $\tau\rceil \sigma \varepsilon v$ dopełnienie bliższe, to wydźwięk tekstu byłby bardzo dokładny i precyzyjny (wąski zakres), tzn. odnosiłby Izaaka do jakiegoś aspektu życia Abrahama. Natomiast dzięki brakowi owego sprecyzowania stych ten posiada wydźwięk bardzo ogólny, który można określić w następujący sposób: podobnie jak Bóg postanowił w stosunku do Abraham, w ten sam sposób (podobnie) zdecydował również w odniesieniu do jego syna, lub podobnie jak Pan działał w życiu praojca Narodu Wybranego, tak samo postępował w historii jego syna. W Syr 44,22a zamiast dopełnienia bliższego znajduje się przysłówek

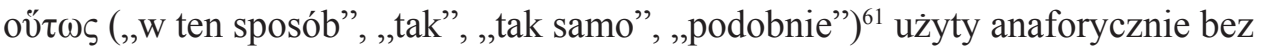

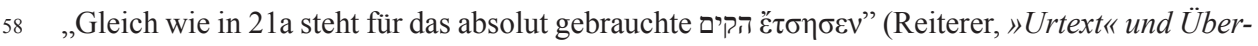
setzungen, 109). Por. tamże, 101.

59 Zob. Muraoka, A Greek-English Lexicon of the Septuagint, 344.

60 Inne thumaczenia greckiej wersji tego stychu: ,,anche a Isacco diede stabilità" (Palmisano, Siracide, 421); „und in Isaak errichtete er ebenso (ein Bund)” (Kraus - Karrer [red.], Septuaginta Deutsch, 1152); ,, i w Izaaku postawił tak” (Ksiegi greckie, 679); ,, and with Isaak he likewise established" (Pietersma - Wright [red.], A New English Translation of the Septuagint, 756); „a Izaakowi tak samo obiecał” (Septuaginta czyli Biblia Starego Testamentu, 1258).

61 Zob. F. Blass - A. Debruner, Grammatica del greco del Nuovo Testamento (Introduzione allo Studio della Bibbia. Supplementi 2; Brescia: Paideia $\left.{ }^{2} 1997\right) \S 434.3$. 
przysłówka korelatywnego ${ }^{62}$, który odnosi się nie do konkretnej rzeczywistości (rzeczy), lecz do sposobu, w jaki została zrealizowana czynnośćc ${ }^{3}$. Dzięki użyciu go tłumacz podkreślił analogię działania Boga w życiu Abrahama i Izaaka.

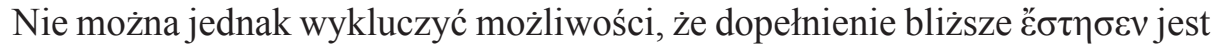
domyślne. W tym wypadku byłyby nim wszystkie obietnice i zapowiedzi, które Bóg złożył Abrahamowi.

Z całą pewnością można stwierdzić, że Syr 44,22a ukazuje Izaaka jako tego, który jest nie tylko synem Abraham, ale przede wszystkim kontynuatorem misji, jaką Bóg powierzył jego ojcu. Najwyższy przyjął wobec niego tę samą postawę, co w stosunku do protoplasty Izraela ${ }^{64}$. $Z$ jednej strony można dzięki temu dostrzec kontynuowanie obietnic uczynionych przez Boga Abrahamowi ${ }^{65}$, z drugiej zaś początek ich realizacji $\mathrm{w}$ dziejach jego rodziny.

Tekst hebrajski Syr 44,22a zawarty w manuskrypcie B stwierdza, że Bóg „również Izaakowi ustanowił syna” (וגם ליצחק הקים בן) ${ }^{66}$. Odnosi się więc on do realizacji obietnic złożonych Abrahamowi, dotyczących jego potomstwa. Należy zwrócić uwagę, że stych ten nie mówi o synach (liczba mnoga), lecz o jednym synu, choć jak wiadomo Izaak miał ich dwóch (Ezawa i Jakuba). Mędrzec koncentruje się więc jedynie na tym spośród nich, który będzie dziedzicem i przedłużeniem rodu patriarchy (Jakubie). Wyraża to wprost w następnym wersecie $(44,23)$. Należy podkreślić i dostrzec fakt, że choć Syrach określił Abrahama jako ojca mnóstwa narodów (אברהם אב המון גוים) ${ }^{67}$, to pominął całkowitym milczeniem część jego rodziny, której protoplastą był Ezaw.

Na marginesie kodeksu B w Syr 44,22 znajduje się lekcja כן (,tak”, „,w ten sposób”) zamiast בן (,syn”) ${ }^{68}$, która w pełni odpowiada tekstowi greckiemu pierwszego stychu tego wersetu i być może pochodzi właśnie z wersji greckiej Syr. Należy zgodzić się z opinią P.C. Beentjesa, że lekcja „syn” lepiej wpisuje

62 Zob. R. Popowski, Wielki stownik grecko-polski Nowego Testamentu. Wydanie z petna lokalizacja greckich haset, kluczem polsko-greckim oraz indeksem form czasownikowych (Prymasowska Seria Biblijna; Warszawa: Vocatio $\left.{ }^{4} 2006\right) 451$.

63 Zob. A Greek-English Lexicon of the New Testament and Other Early Christian Literature (Chicago - London: The University of Chicago Press $\left.{ }^{2} 1979\right) 597$.

64 „Just as in the Hebrew Bible, Isaac appears to be a mere copy of his father's vicissitudes, which in the Ben Sira text are summarized in the Phrase 'Also with Isaac he established thus, on account of Abraham his father' (44:22ab)” (Beentjes, „Ben Sira 44:19-23 - The Patriarchs Text, Tradition, Theology", 216).

65 Zob. Petraglio, Il libro che contamina le mani, 79.

66 Wielu badaczy hebrajski tekst Syr 44,22a tłumaczy w następujący sposób: „i również Izaakowi przysiągł syna" (por. Mopsik, La Sagesse de ben Sira, 280; Morla, Los manuscritos hebreos de Ben Sira. Traducción y notas, 286; Palmisano, Siracide, 420; http://bensira.org/navigator. php?Manuscript=B\&PageNum=27 [dostęp: 20.05.2018]).

67 Na temat relacji tekstu hebrajskiego do greckiego Syr 44,22a zob. Reiterer, »Urtext« und Übersetzungen, 109 .

68 Zob. Skehan - Di Lella, The Wisdom of Ben Sira, 504. 
się w kontekst Syr 44,19-22 ${ }^{69}$ (przeciwnego zdania są R. Petraglio ${ }^{70}$, J. Schreiner ${ }^{71}$ i F.V. Reiterer ${ }^{72}$ ), choć $\mathrm{Syr}^{73}$. Słowa „Abraham” i „ojciec” w Syr 44,22 tworzą inkluzję z Syr 44,19a (,Abraham ojciec mnóstwa narodów”), natomiast początkowe słowa Syr 44,22a: „dla Izaaka ustanowił tak” (lekcja z marginesu manuskryptu) łączą się z , dlatego przysięgą ustalił mu [Abrahamowi - przyp. autora]" (Syr 44,21a).

Zdaniem R. Petraglio i F.V. Reiterera, Syr 44,22a jest nawiązaniem do Rdz 26,3. Pierwszy ze wspomnianych egzegetów swą opinię opiera na użyciu w obu tekstach czasownika קום (G. Sauer określa go jako kluczowy w odniesieniu Izaaka do Abrahama - 44,21c; jego zdaniem, słowo to odnosi przymierze, które Bóg zawarł z Abrahamem do jego syna ${ }^{75}$ ). Wydaje się jednak, że jest to zbyt słaby argument, aby na tej podstawie połączyć oba teksty i widzieć w Syr 44,22a odniesienie do wspomnianego wersetu z Rdz. F.V. Reiterer zależność Syr 44,22a od Rdz 26,3 opiera zaś na treści obu tekstów ${ }^{76}$.

Drugi stych poświęcony w Pochwale Ojców Izaakowi (Syr 44,22b) podaje przyczynę, dla której Bóg postąpił z nim w ten sam sposób, jak z jego ojcem

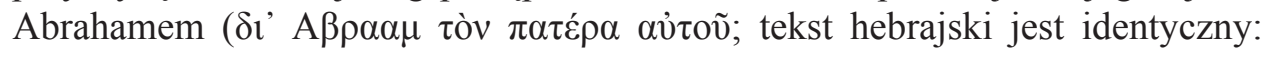
בעבור אברהם אבין). Należy zwrócić uwagę na fakt, że zarówno tekst grecki, jak i hebrajski tego stychu są cytatami Rdz 26,2477. To właśnie ze względu na Abrahama Bóg obdarzył jego syna tymi samymi łaskami i darami, co jego ojca. W ten sposób Syrach nie przypisał Izaakowi żadnej wyjątkowej i specyficznej roli

69 Zob. Beentjes, „Ben Sira 44:19-23 - The Patriarchs Text, Tradition, Theology”, 216.

$70, \ldots[. .$.$] la promessa a Isacco ha lo stesso contenuto di quella fatta ad Abramo, precis ache Dio$ a Isacco promise in giuramento 'allo stesso modo'. Così si legge in margine al testo ebraico di $\operatorname{Sir} 44,22$; evidente questa è la variante migliore e va considerata come la giusta correzione nei confronti del testo dove si legge "un figlio" (Petraglio, Il libro che contamina le mani, 79).

71 „So ist wohl $k l \mathrm{H}^{\mathrm{Bmg}}$, die bessere Lesart gegenüber $b n \mathrm{H}^{\mathrm{B}}$, zu deuten, da es sich hier um den Bund handelt, nicht um einen Nachkommen” (J. Schreiner, „Patriarchen im Lob der Väter [zu Sir 44]", Textarbeit: Studien zu Texten und ihrer Rezeption aus dem Alten Testament und der Umwelt Israels [FS P. Weimar] [red. K. Kiesow - T. Meurer] [AOAT 294; Münster: Ugarit-Verlag 2003] 439 przyp. 59).

72 „Am Ende von 22a liest mann ach B הקים בן; dies ergibt einen Sin. Auch kann man nachweisen, daß die ,Errichtung' eines Nachkommen ähnlich zum Ausdruck gebracht werden kann. - Doch fügt sich dieser Satz dann nicht in den Kontext ein, sodaß man Bm den Vorzug geben wird und statt כן annimmt” (Reiterer, »Urtext« und Übersetzungen, 108).

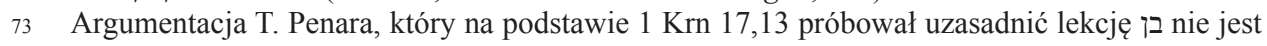
przekonująca (zob. T. Penar, Nortwest Semitic Philology and the Hebrew Fragments of Ben Sira [BibOr 28; Rome: Biblical Institute Press 1975] 78).

74, ,... [ in 22a Ben Sira riprende Gen 26,3; là c'era l'espressione 'mantenere il giuramento'. L'autore riprende lo stesso verbo ebraico (qum) sottintendendo l'oggetto 'giuramento' o 'alleanza'" (Petraglio, Il libro che contamina le mani, 79).

75 „Durch 'sicherte er zu', hebr. Hqjm greift der mit Isaak befasste ${ }^{22}$ ein zentrales Stichwort aus ${ }^{21}$ auf, das die Verheißung Gottes an Abraham einleitet” (Zapff, Jesus Sirach 25 - 51, 323).

76 Zob. Reiterer, »Urtext « und Übersetzungen, 109.

77 Zob. Palmisano, Siracide, 420; Zapff, Jesus Sirach 25 - 51, 323. 
w historii rodziny Abrahama i całego Narodu Wybranego. Podobnie jak w tekście Księgi Rodzaju, również w Syr 44,22 rolą tego patriarchy jest bycie jedynie pomostem i łącznikiem pomiędzy Abrahamem i Jakubem ${ }^{78}$ - ojcem dwunastu synów, który dał początek pokoleniom Izraela zgodnie z zapowiedzią wyrażoną w Rdz $17,19^{79}$. Powyższą opinię potwierdza R. Petraglio, stwierdzając, że Izaak jest jedynie beneficjentem błogosławieństwa, przymierza i obietnic złożonych Abrahamowi ${ }^{80}$. J. Schreiner idzie jeszcze dalej, deklarując, że Izaak w Pochwale Ojców nie ma własnego profilu ${ }^{81}$.

Kolejny stych Syr 44,22-23 stanowi poważny problem (zostało to już wspomniane wcześniej). Uwidacznia się on w jego numeracji w poszczególnych wydaniach zarówno tekstu oryginalnego, jak i tłumaczeń Księgi Mądrości Syracha. Wiele spośród nich zalicza go do Syr 44,22, określając te słowa jako 44,22 c $\mathrm{c}^{82}$, inne zaś uznają je za pierwszy stych Syr 44,2383. Przyczyną owego zamieszania $\mathrm{z}$ odpowiednim przypisaniem omawianego stychu do pochwały Izaaka czy Jakuba jest różnica pomiędzy hebrajskim oryginałem tego stychu a jego greckim tłumaczeniem. W tekście oryginalnym w ostatnim słowie występuje zaimek trzeciej osoby liczby pojedynczej (נתנו - ,dał mu”), co sprawia, że cały ten stych należy odnieść do Izaaka ${ }^{84}$. Tłumaczenie zaś tego tekstu na język grecki nie zawiera

78 „Er [Izaak - przyp. autora] hat die Aufgabe, den Bund mit Gott, den Abraham- und den Noach-Bund durch seinen Segen (Gen 27,1-29) auf Jacob zu übertragen” (Schreiner, „Patriarchen im Lob der Väter [zu Sir 44]”, 440). Opinię tę potwierdza G. Sauer: „An dem Leben Isaaks ist nur wichtig, daß er in der Traditionskette, die durch Abraham begründet wurde, steht" (Sauer, Jesus Sirach/Ben Sira, 305). Por. T. Maertens, L'Éloge des Pères (Ecclesiastique XLIV-L) (Lumiere et Vie 5; Bruges: Editions de l'Abbaye de Saint-Andre 1956) 55. Zdaniem zaś B.M. Zappfa, celem Syr 44,22 jest uzmysłowienie wierności Bogu i pobożności Abrahama pokoleniom, które po nim nastąpią (zob. Zapff, Jesus Sirach 25 - 51, 323).

79 Zob. Schreiner, „Patriarchen im Lob der Väter (zu Sir 44)”, 439-440.

80 Zob. Palmisano, Siracide, 420; G. Pérez Rodríguez, „Eclesiástico”, Biblia Comentada IV. Libros Sapienciales (Biblioteca de Autores Cristianos 218; Madrid: La Editorial Catolica 21967) 1275; Petraglio, Il libro che contamina le mani, 79.

81 Zob. Schreiner, „Patriarchen im Lob der Väter (zu Sir 44)”, 439.

82 Zob. The Book of Ben Sira. Text, Concordance and an Analysis of the Vocabulary, 54; Mopsik, La Sagesse de ben Sira, 280; Morla, Los manuscritos hebreos de Ben Sira. Traducción y notas, 286; Peters, Das Buch Jesus Sirach oder Ecclesiasticus, 380; tenże, Der jüngst wiederaufgefundene Hebräische Text des Buches Ecclesiasticus, 233; Ziegler, Sapientia Iesu Filii Sirach, 334; $\mathrm{http} / / /$ bensira.org/navigator.php?Manuscript=B\&PageNum=27 [dostęp: 20.05.2018].

83 Zob. Rahlfs (red.), Septuaginta, II, 456. P.C. Beentjes w swoim wydaniu tekstu hebrajskiego Syr zaproponował, aby nie tylko ten stych, ale również kolejny, w którym zostało wymienione imię Izrael, zaliczyć do Syr 44,22 (zob. Beentjes, The Book of Ben Sira in Hebrew, 78). Por. Beentjes, „Ben Sira 44:19-23 - The Patriarchs Text, Tradition, Theology”, 211.217.

84 "Some maintain that both Sir 44:22c and 44:23a have a bearing on Jacob/Israel. Other Ben Sira scholars, on the contrary, hold the view that Sir 44:22c touches upon Isaac, whereas Sir 44:23a refers to Jacob/Israel. To my mind, the Hebrew text of 44:22c according to MS B. allows no other possibility but to have reference to Isaac, being the antecedent of ונתנ ('He gave him')" (Beentjes, „Ben Sira 44:19-23 - The Patriarchs Text, Tradition, Theology”, 217). Jednak nie wszyscy tak uważają: ,[...] St III ist gegen Gr mit Syr, wie der Parallelismus lehrt und לכ zeigt, 


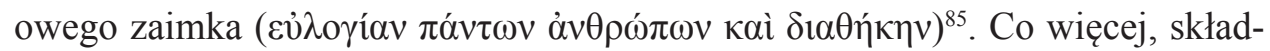

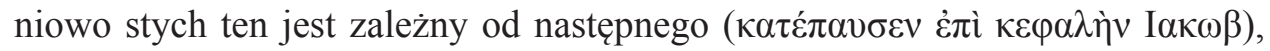

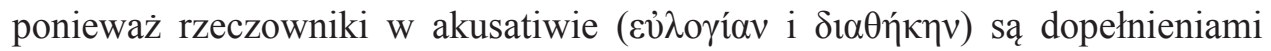

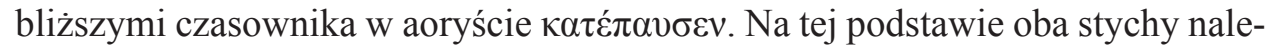
ży połączyć razem i uznać, że wyrażają pochwałę Jakuba.

Ponieważ w hebrajskiej wersji Syr problematyczny stych jednoznacznie odnosi się do Izaaka, dlatego też zostanie omówiony jako kontynuacja pochwały tego patriarchy. Syr 44,22c(23a) zawiera słowa: ברית כל ראשון נתנו ${ }^{86}$ (,przymierze każdego poprzedniego dał mu"87). Zdaniem P.C. Beentjesa, Syrach wybrał odpowiednie słownictwo, aby podkreślić rolę Izaaka. Bóg sprawił, że uczestniczy on we wszystkich wcześniejszych przymierzach ${ }^{88}$, nie tylko tym zawartym z jego ojcem Abrahamem (Syr 44,20; por. Rdz 12,2-3.7; 15,18; 17,1-8.19; 22,17-18; 26,3-5.24) ${ }^{89}$, ale również z Noem (Syr 44,18; por. Rdz 9,11-17) ${ }^{90}$. Należy zwrócić uwagę na fakt, że słowa נתן ברית znajdują się jedynie w Rdz 17,2 (przymierze z Abrahamem) i Lb 25,12 (przymierze z Pinchasem; por. Syr 45,23-24) w całej Biblii hebrajskiej ${ }^{91}$. Nie można wykluczyć możliwości, że właśnie w ten sposób mędrzec chciał ponownie nawiązać i położyć akcent na Rdz $17^{92}$ - tekście, który odegrał tak wielką rolę w pochwale Abrahama (Syr 44,19-21) ${ }^{93}$. Być może użycie syntagmy נתן ברית w hebrajskiej wersji Syr 44,22c poprzez nawiązanie do Rdz 17,2 i Lb 25,12 mogło wyrażać ideę, że przymierze, o którym mowa nie odnosiło się jedynie do Izaaka, ale również do jego potomstwa (analogicznie jak w wypadku Abrahama i Pinchasa). Jeśli tak, to mędrzec z Jerozolimy pragnął podkreślić, że również ten patriarcha jest podmiotem zobowiązania, jakie Bóg przyjął na

zum Folgenden zu ziehen” (Peters, Das Buch Jesus Sirach oder Ecclesiasticus, 382). „St. III gehört zur Darstellung des Jakob, nicht des Isaak" (Peters, Der jüngst wiederaufgefundene Heרי לכ תירב ist als Prädikche Text des Buches Ecclesiasticus, 223; por. tamże, 233). ונתני möglich und daher nicht anzufechten" (Smend, Die Weisheit des Jesus Sirach erklärt, 425). Por. także Reiterer, »Urtext« und Übersetzungen, 109-110.

85 Zob. Morla, Los manuscritos hebreos de Ben Sira. Traducción y notas, 287; Smend, Die Weisheit des Jesus Sirach erklärt, 425.

$86 \mathrm{Na}$ temat relacji tekstu hebrajskiego Syr 44,22c do wersji greckiej tego stychu zob. Reiterer, "Urtext" und Übersetzungen, 110; Smend, Die Weisheit des Jesus Sirach erklärt, 425. M.C. Palmisano uważa, że stych ten nie daje się całkowicie zrozumieć (zob. Palmisano, Siracide, 420).

87 R. Smend słowa te thumaczy w inny sposób: „Der Bund aller Vorfahren wurde gelegt” (Smend, Die Weisheit des Jesus Sirach hebräisch und deutsch, 79). Należy jednak podkreślić, że w tłumaczeniu tym Smend nie tylko pominął w נתנו sufiks, ale ponadto nadał tej formie znaczenie strony biernej (zob. Beentjes, „Ben Sira 44:19-23 - The Patriarchs Text, Tradition, Theology”, 217 przyp. 31).

88 Zob. Zapff, Jesus Sirach 25 - 51, 324.

89 Zob. Petraglio, Il libro che contamina le mani, 79.

90 Zob. Skehan - Di Lella, The Wisdom of Ben Sira, 505; Zapff, Jesus Sirach 25 - 51, 323-324. Por. Maertens, L'Éloge des Pères (Ecclesiastique XLIV-L), 60.

91 Zob. Reiterer, »Urtext" und Übersetzungen, 111.

92 Zob. Reiterer, »Urtext« und Übersetzungen, 109.

93 Zob. Beentjes, „Ben Sira 44:19-23 - The Patriarchs Text, Tradition, Theology”, 224. 
siebie w stosunku do jego ojca - Abrahama. Potwierdza to F.V. Reiterer, który interpretuje przesłanie Syr 44,22c w tym sensie, że Bóg zawarł przymierze z Abrahamem, a następnie odnowił je z Izaakiem (por. Rdz 26,2-5) ${ }^{94}$.

Podsumowując Syr 44,22, można stwierdzić, że Syrach w swojej pochwale Izaaka oparł się całkowicie na tekście Księgi Rodzaju. Patriarcha ten nie wniósł, zdaniem mędrca z Jerozolimy, niczego nowego do historii rodziny Abrahama. Był wyłącznie nośnikiem i przekazicielem (kontynuatorem i pośrednikiem) przymierza i obietnic swego ojca ${ }^{95}$. Potwierdza to całkowicie początkowe przypuszczenie odnoszące się do faktu, że mędrzec z Jerozolimy poświęcił Izaakowi tak mało miejsca w Pochwale Ojców. Syrach w opisie postaci „syna obietnicy” pominął całkowitym milczeniem konflikt $\mathrm{z}$ jego bratem Izmaelem oraz trudności związane z życiem rodzinnym tego patriarchy, tak aby całkowicie skoncentrować się na obietnicach złożonych Abrahamowi ${ }^{96}$.

\section{Jakub}

Znacznie więcej miejsca w Pochwale Ojców Syrach poświęcił synowi Izaaka - Jakubowi. W wersji greckiej do niego odnosi się 6 stychów ( $5 \mathrm{w}$ wersji hebrajskiej; zob. powyżej problem związany z Syr 44,22c), podczas gdy w Księdze Rodzaju cały cykl opowiadań poświęconych temu patriarsze jest dość obfity (Rdz 25,19 - 50,26). R. Petraglio podkreśla, że bardzo rzucająca się w oczy jest różnica pomiędzy wieloma informacjami na temat Jakuba, których dostarcza pierwsza księga Pisma Świętego, a tym, co napisał o nim Syrach ${ }^{97}$.

Ponieważ dla podjętej w tym artykule analizy Syr 44,22-23 fundamentalny jest tekst grecki, dlatego kontrowersyjny werset 44,23a (zob. powyżej) wersji greckiej tekstu zostanie omówiony jako słowa należące do pochwały Jakuba.

94 Zob. Reiterer, »Urtext« und Übersetzungen, 109.

95 „La posizione di Isacco è centrale, è un punto decisivo: permette all'alleanza, o meglio all'impegno unilaterale di Dio, di raggiungere tutti i popoli passando attraverso i loro capostipiti" (Petraglio, Il libro che contamina le mani, 79). Por. J.G. Snaith, Ecclesiasticus or The Wisdom of Jesus Son of Sirach (The Cambridge Bible Commentary; Cambridge: Cambridge University Press 1974) 219.

96 „A Isacco Ben Sira dedica solo un verso. Di fronte al 'poco' materiale che la Genesi contiene su Isacco, Ben Sira fa le sue scelte. Innanzitutto 'dimentica' la tensione rappresentata da Ismaele accanto a Isacco o, se si vuole risalire di una generazione, da Agar accanto a Sara. Egli dimentica il dramma carico di umanità vissuto da Agar e Ismaele. Dimentica pure il matrimonio con Rebeca e i dolori legati alla sua vita famigliare. Dimentica anche i problemi connessi con il suo stile di vita nomade" (Petraglio, Il libro che contamina le mani, 78-79). Por. Pérez Rodríguez, „Eclesiástico”, 1275.

97 „A prima vista si può notare l'enorme distanza tra quanto Ben Sirac dice di Giacobbe e quanto poteva leggere nella bibbia. Ben Sirac non cita l'AT, scrive di proprio pugno, forgiando egli stesso le sue formulazioni" (Petraglio, Il libro che contamina le mani, 86). 
Syrach prezentację wnuka Abrahama rozpoczyna od stwierdzenia, że Bóg (On, podobnie jak w Syr 44,22, jest podmiotem wszystkich form czasownikowych

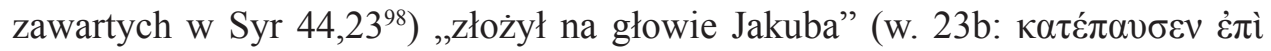

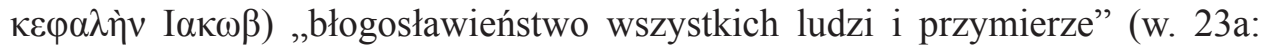

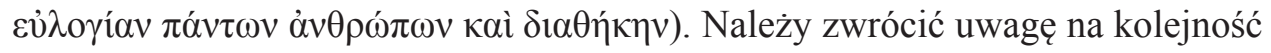
tych dwóch stychów. Na ogół w języku greckim dopełnienie bliższe znajduje się po czasowniku, który się go domaga. W Syr 44,23ab powyższa kolejność została odwrócona. Wydaje się, że thumacz tekstu oryginalnego pragnął w ten sposób podkreślić i uwydatnić to, czym patriarcha został obdarowany przez Pana bardziej niż sam fakt otrzymania darów od Boga.

Pierwszym darem, który Jakub otrzymał od Najwyższego, jest błogosławieństwo wszystkich ludzi ( w greckiej wersji dzieła Syracha występuje dziewiętnaście razy (w tym dwa razy w 44,23) ${ }^{99}$. Słowo to określa zarówno błogosławieństwo ze strony ludzi, jak i Boga. Ten, kto czci swego ojca, otrzyma je od niego $(3,8 b)$, ono umacnia domy (3,9a), zaś przekleństwo matki wykorzenia fundamenty $(3,9 b)$. W Syr 3,9 błogosławieństwo zostało przeciwstawione przekleństwu. Tekst ten odnosi się do zwyczaju błogosławienia dzieci przez ich rodziców, czyli przekazywaniu im w sposób oficjalny prawa dziedziczenia oraz ich życzliwości i wsparcia (por. Rdz 27; 48-49) ${ }^{100}$. Grecka wersja Syr dwukrotnie mówi również o błogosławieństwie ze strony ludzi, które ma być kontynuowane w pamięci potomnych za niezwykłe dzieła, których dokonał Mojżesz $(45,1)$ i sędziowie $(46,11)$. W tym wypadku jest ono rozumiane jako wdzięczność za nadzwyczajne czyny, których oni dokonali na rzecz swego narodu oraz pamięć o ich wierności Bogu. Znacznie

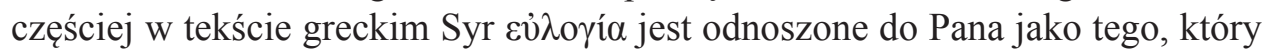
błogosławi i obdarza swoją łaską konkretne osoby. Najwyższy udziela pełni błogosławieństwa tym, którzy wspierają ubogich (7,32; por. 40,17: „Łaskawość jest jak raj wśród błogosławieństw”). Jest ono nagrodą dla pobożnych $(11,22 a)$, z której bardzo szybko mogą oni się cieszyć $(11,22 b)$. Bóg nie zwleka z jego udzieleniem, ale obdarza nim natychmiast tych, którzy są Mu wierni. Również miłujący Pana otrzymują od Niego błogosławieństwo $(34,17)$. Także mędrzec zostanie nim wypełniony $(37,24)$. Bojaźń Pańska jest jak raj błogosławieństwa (40,27; por. 40,17). Syrach, modląc się do Boga o wybawienie Izraela, błaga Go, aby udzielił On błogosławieństwa Aaronowego (Lb 6,24-27) swemu ludowi (Syr 36,16). W 33,17 sam mędrzec uznał, że pracy jego towarzyszyło błogosławieństwo Boże i dzięki niemu mógł on ukończyć swe dzieło. Najwyższy jest bowiem

98 Zob. Palmisano, Siracide, 420.

99 Na temat błogosławieństwa w Syr zob. Maertens, L'Éloge des Pères (Ecclesiastique XLIV-L), 61-62.

100 Zob. L. Ryken - J.C. Wilhoit - T. Longman III, Le immagini bibliche. Simboli, figure retoriche e temi letterari della Bibbia (Dizionari San Paolo; Cinisello Balsamo: San Paolo 2006) 189. 
bardzo hojny, a Jego błogosławieństwo zalewa świat tak jak rzeka, która daje życie $(39,22)$. Dawid był sławiony z powodu błogosławieństwa Bożego $(47,6)$, zaś arcykapłan Szymon przekazywał je ludowi $(50,20)$, który przyjmował je, oddając pokłon Bogu $(50,21)$. Błogosławieństwo jest wyrażonym słownie darem, który nie określa konkretnego przedmiotu, lecz odnosi się do sfery bycia $\mathrm{i}$ jest wyrazem działania boskiej mocy wobec człowieka otrzymującego je. „Błogosławieństwo oznacza więc dar stwórczy i ożywiający albo na tym etapie, kiedy on jeszcze nie zaistniał, i wtedy chodzi o modlitwę, albo stadium jego posiadania już, i wówczas mamy do czynienia z wyrazami wdzięczności"101. Skutkiem jego udzielenia jest dobrobyt materialny i powodzenie życiowe na różnych płaszczyznach egzystencji człowieka, które Żydzi bardzo często określali mianem po-

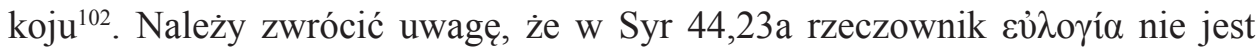
poprzedzony rodzajnikiem. Chodzi więc nie o konkretne błogosławieństwo (jednostokowe), ale o naturę błogosławieństwa, czyli dary, które ono z sobą niosło.

Według greckiego tłumaczenia Syr 44,23a, Jakub otrzymał błogosławieństwo, czyli duchowe i materialne dary, które zostały udzielone wszystkim in-

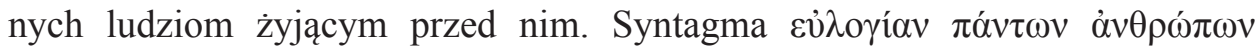
z punktu widzenia składni języka greckiego może być interpretowana na kilka różnych sposobów, które odmiennie określają odniesienie 'błogosławieństwa' do 'wszystkich ludzi'. Po pierwsze, dopełniacz $\pi \alpha ́ v \tau \omega v ~ \alpha ̉ v \theta \rho \omega ́ \pi \omega v$ można uznać za genetivus possessoris (błogosławieństwo, które jest własnością wszystkich ludzi), genetivus obiectivus (błogosławieństwo dotyczące wszystkich ludzi - oni są podmiotem, który je otrzymał/otrzymuje) lub subiectivus (błogosławieństwo, którego udzielili wszyscy ludzie), originis (błogosławieństwo pochodzące od wszystkich ludzi) bądź causae (błogosławieństwo z powodu wszystkich ludzi). Pomimo trudności związanych z jednoznacznym i dokładnym określeniem rela-

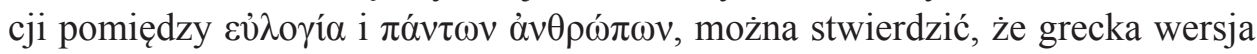
tekstu Syr 44,23a odnosi do Jakuba wszystkie błogosławieństwa, które zostały wypowiedziane zarówno przez Boga, jak i ludzi. W nim niejako zostały one skumulowane, co sprawia, że stał się on najbardziej obdarowanym ze wszystkich ludzi przed nim żyjących. Jest on „najbardziej błogosławionym” z całej współczesnej mu i żyjącej do tej pory ludzkości. Syrach w Pochwale Ojców przedstawia swoją wizję historii Izraela, więc wydaje się słusznym założenie, że $\pi \alpha ́ v \tau \tau v$ $\grave{\alpha} v \theta \rho \omega ́ \pi \omega v$ odnosi się do ludzi, którzy żyli do czasów Jakuba, a nie do absolutnie

101 J. Guillet, „Błogosławieństwo”, Słownik teologii biblijnej (red. X. Leon-Dufour) (Poznań: Pallottinum 1990) 79.

102 Zob. B. Balembo, „Benedizione”, Temi teologici della Bibba (ed. R. Penna - G. Perego - G. Ravasi) (Dizionari San Paolo; Cinisallo Balsamo: San Paolo 2010) 133; Guillet, „Błogosławieństwo", 79-80; H. Obermayer - K. Speidel - K. Vogt - G. Zieler (red.), Piccolo dizionario biblico (Cinisello Balsamo: San Paolo 1988) 54; Ryken - Wilhoit - Longman III, Le immagini bibliche, $189 ;$ K.H. Richards, „Bless/blessing”, The Anchor Bible Dictionary (red. D.N. Freedman) (New York - London - Toronto: Doubleday 1992) I, 754. 
całej ludzkości wszystkich czasów. Interpretację tę potwierdza wersja hebrajska, mówiąca o każdym poprzednim (zob. powyżej Syr 44,22c). T. Maertens uważa

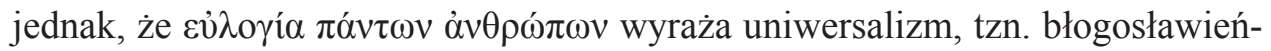
stwo, o którym jest mowa w Syr 44,23a, podobnie jak to wyrażone w Syr 44,21b („będą błogosławione narody za pośrednictwem potomstwa jego”), jest skierowane do wszystkich ludzi ${ }^{103}$. Natomiast A.A. Di Lella twierdzi, że Syr 44,23ab nawiązuje do wykradzenia błogosławieństwa Izaaka przez Jakuba i tego konsekwencji (por. Rdz 27,1-29 oraz 28,3-4) ${ }^{104}$. M.C. Palmisano i B.M. Zapff sądzą, że powyższe dwa stychy z Syr czynią aluzję jedynie do Rdz 27,27105. Jest to jednak zbyt ograniczona interpretacja, ponieważ należy zwrócić uwagę na fakt, że błogosławieństwo jest jednym $\mathrm{z}$ głównych tematów teologicznych w całym cyklu o Jakubie (por. Rdz 27,12.35-36.41; 28,4) ${ }^{106}$.

Drugim darem, który otrzymał Jakub jest przymierze $(\delta i \alpha \theta \eta \dot{\kappa} \eta)^{107}$. Pierwszy (błogosławieństwo) określa to, czym został on obdarowany, choć czyni to w sposób bardzo ogólny i szeroki, drugi zaś wyraża relację patriarchy w stosunku do Boga. Jakub podobnie jak jego ojciec jest nośnikiem przymierza i jego przekazicielem. Pełni więc poniekąd tę samą rolę, która została przypisana przez mędrca

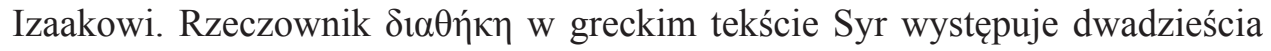
trzy razy. Najczęściej za jego pomocą określone zostało przymierze zawarte z Izraelem na Synaju za pośrednictwem Mojżesza ${ }^{108}$, dlatego dwadzieścia jeden razy występuje ono w liczbie pojedynczej i tylko trzy w mnogiej (44,12; 44,18 i 45,17). W 14,12.17 odnosi się ono nie do przymierza rozumianego jako układ pomiędzy dwoma stronami, lecz wyraża prawo przyrody - natury, zgodnie z którym człowiek starzeje się i umiera. W Syr 24,23 mędrzec utożsamił mądrość z księgą przymierza Najwyższego, którą jest Prawo. W pozostałych tekstach,

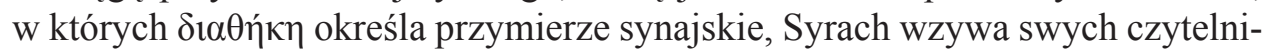
ków do wierności i zachowywania go $(11,20 ; 16,22 ; 28,7 ; 38,33)$ oraz by się go

103 „L'expression d'Ecclésiastique XLIV, 21 «bénir toutes les nations en ta descendance» et celle d'Ecclésiastique XLIV, 23: «la bénédiction de tous les hommes reposa sur la tête de Jacob» s'expliquent très bien dans cette ambiance sacerdotale et universaliste: la transmission du dessein de Dieu n'est plus seulement le fait d'un patriarche disant adieu à son fils, c'est tout un people qui devient bénédiction pour le mond entier, lui révélant le plan de Deiu sur lui et le réalisant en lui [...]. Pour exprimer cette doctrine universaliste, Ben Sira proclame que reposa sur Jacob «la bénédiction de tous les hommes», expression qui, pour le moins, constitue une amplification considérable du récit de la Genèse et introduit - c'est la seule fois à notre connaissance - le thème de la bénédiction universelle dans un discours d'adieux patriarcal" (Maertens, L'Éloge des Pères [Ecclesiastique XLIV-L], 64).

104 Zob. Skehan - Di Lella, The Wisdom of Ben Sira, 505.

105 Zob. Palmisano, Siracide, 421; Zapff, Jesus Sirach 25 - 51, 324.

106 Zob. Beentjes, „Ben Sira 44:19-23 - The Patriarchs Text, Tradition, Theology”, 224.

107 Na temat przymierza w Syr zob. Maertens, L'Éloge des Pères (Ecclesiastique XLIV-L), 60-61; Schreiner, „Patriarchen im Lob der Väter (zu Sir 44)”, 436-437.

Zob. Syr 11,$20 ; 16,22 ; 17,12 ; 24,23 ; 28,7 ; 38,33 ; 39,8 ; 41,20 ; 42,2$. 
nie wstydzili $(39,8 ; 42,2)$. Potępia również zapominanie o nim $(41,20)$. Najczęściej, gdy tekst grecki mówi o zawarciu przymierza przez Boga z kimś, używa

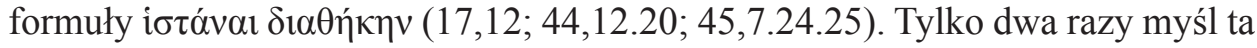

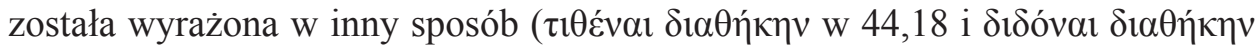
w 47,11). Syr 45,15c mówi zaś o staniu się przymierza dla Aarona ( $\dot{\varepsilon} \gamma \varepsilon v \eta ́ \theta \eta ~ \alpha \vartheta ่ \tau \tilde{~}$

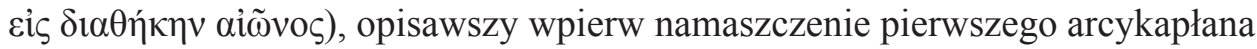

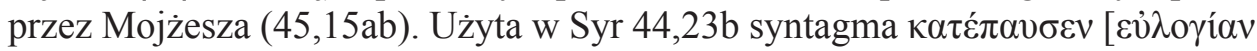

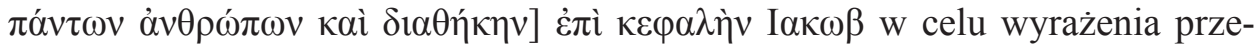
kazania Jakubowi błogosławieństwa i przymierza jest wyjątkowa i jedyna nie tylko w dziele Syracha, ale również w całej Septuagincie (nigdzie w greckim

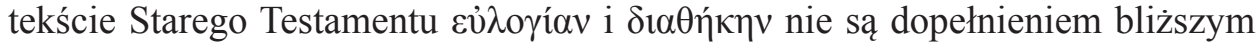

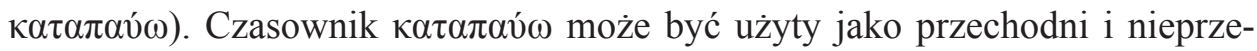
chodni ${ }^{109}$. W greckim tekście dzieła mędrca $\mathrm{z}$ Jerozolimy występuje on siedem razy: sześć jako przechodni i jeden raz jako nieprzechodni $(47,13)$. Bóg wymazał

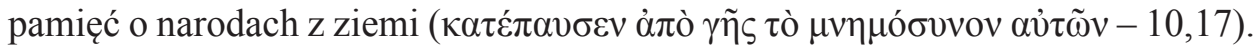
W 38,23 Syrach wzywa, aby pamięć o zmarłym spoczęła z nim ( $\dot{\varepsilon} v \dot{\alpha} v \alpha \pi \alpha v ́ \sigma \varepsilon 1$

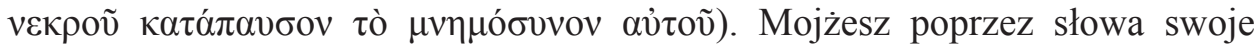

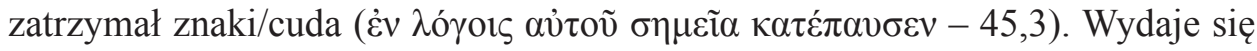
jednak, że w perspektywie interpretacji Syr 44,23b najważniejsze teksty zawierające analizowany czasownik znajdują się w Syr 24 - w autoprezentacji Mądrości. W 24,8 Mądrość mówi, że Bóg kazał jej zamieszkać w Jakubie i w Izraelu objąć

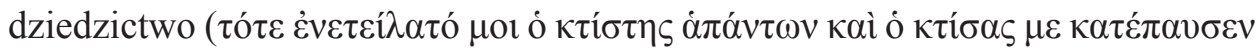

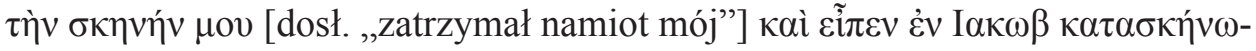

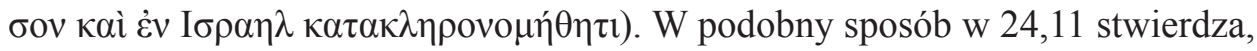
że w mieście umiłowanym, tzn. w Jerozolimie ( $\dot{\varepsilon} v$ I I $\rho \circ v \sigma \alpha \lambda \eta \mu)$, zatrzymał ją ( $\dot{\varepsilon} v$

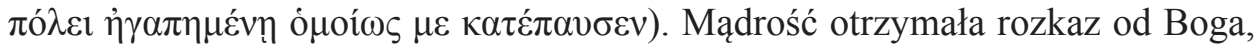
aby zamieszkała (dosł. Pan zatrzymał ją) w Jerozolimie. Ona zaś posłuszna Jego nakazowi osiadła w niej i nadal tam przebywa. Warto zwrócić uwagę, że w Syr 24,8 jest mowa o Jakubie jako miejscu spoczęcia mądrości, zaś 44,23b stwierdza, że Bóg złożył (zatrzymał) błogosławieństwo i przymierze na głowie tegoż

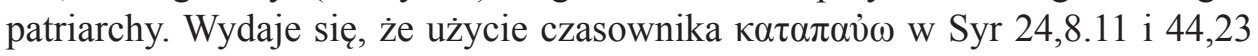
nie jest przypadkowe, zwłaszcza jeśli weźmiemy pod uwagę wyjątkowość frazy

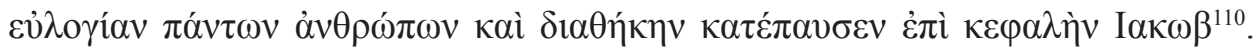
Poprzez użycie jej tłumacz hebrajskiego oryginału na język grecki najprawdo-

109 Zob. Muraoka, A Greek-English Lexicon of the Septuagint, 379; Smend, Die Weisheit des Jesus Sirach erklärt, 425.

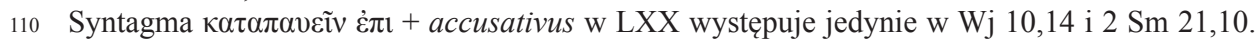
Pierwszy z tych tekstów odnosi się do szarańczy, osiadła (zatrzymał ją Pan) na wszystkich regionach Egiptu. Drugi zaś opisuje jak to Resfa córka Aji wzięła materiał włosiany, przytwierdziła go do skały i mieszkała pod nim aż do dnia, gdy spadł deszcz. Nie pozwalała ona, aby ptaki siadały na niego (dosł. zatrzymywały się na nim) podczas dnia. 
podobniej chciał celowo nawiązać do Syr 24,8.11111. Zamiarem jego było podkreślenie i uwypuklenie prawdy, że w Jakubie - Izraelu Bóg złożył niezwykłe i wyjątkowe swoje dary: mądrość, błogosławieństwo i przymierze. W ten sposób stał się on depozytariuszem niezwykłej łaskawości Najwyższego. Z jego skarbu mogą korzystać również inne narody, jeśli tylko w nim będą szukały tych niezwykłych dóbr i Bożych skarbów.

Tekst hebrajski Syr 44,23a, jak zostało wspomniane wcześniej, odnosi się do Izaaka (zob. powyżej), stwierdzając, że ,przymierze każdego poprzedniego dał (Bóg przyp. autora) mu”. Oryginalna wersja Syr 44,23b mówi, że Bóg oparł na głowie Izraela błogosławieństwo (וברכה נחה על ראש ישראל). Dostrzegamy znaczącą różnicę pomiędzy wersją hebrajską a grecką Syr 44,23ab ${ }^{112}$. Pierwsza z nich stwierdza, że Jakub/ Izrael otrzymał tylko błogosławieństwo, druga zaś przypisuje mu zarówno przymierze, jak i błogosławieństwo. Według tekstu greckiego wnuk Abrahama został bardziej obdarzony niż według hebrajskiego oryginału. Tłumaczenie greckie wywyższa więc bardziej Jakuba nad jego ojca niż pierwowzór, który wyszedł spod pióra Syracha. Odniesienie do Jakuba jedynie błogosławieństwa w tekście hebrajskim być może miało na celu podkreślenie i wyeksponowanie głównego wątku cyklu opowiadań poświęconych mu w Rdz. To właśnie błogosławieństwo, o czym mówiono już wcześniej, jest jednym z głównych tematów teologicznych w opowiadaniach poświęconych temu patriarsze $^{113}$. P.C. Beentjes zwraca uwagę na fakt, że trudno jest uniknąć wrażenia, że tekst hebrajski zawiera bardzo subtelną grę słów pomiędzy ראשון w 44,22c/23a i ראש $\mathrm{w}$ stychu następnym ${ }^{114}$. Niestety badacz ten dostrzega jedynie powyższy fakt, ale ani nie wyjaśnił, jakie ma on znaczenie, ani nie podał jego przyczyn ${ }^{115}$.

Bardzo interesująca jest również zmiana imienia patriarchy z 'Izrael' (wersja hebrajska) na 'Jakub' (wersja grecka). Najprawdopodobniej było to uwarunkowane środowiskiem diaspory (Aleksandria), w którym dokonano thumaczenia dzieła Syracha na język grecki. Aby odpowiedzieć wyczerpująco na pytanie dotyczące owej zamiany imienia w Syr 44,23b, należałoby dokładnie zbadać relacje pomiędzy Żydami i mieszkańcami Aleksandrii oraz rolę, jaką w czasach wczesnego judaizmu pełnił Jakub w środowisku (kultura i religia) judaistycznym. Ponieważ problem ten wykracza poza zakres niniejszego artykułu, dlatego też nie będziemy się nim zajmować. N. Peters uważa, że zmiana oryginalnego imienia 'Izrael' na 'Jakub' w tekście greckim zapobiega ewentualnemu niepoprawnemu zrozumieniu tego stychu ${ }^{116}$.

111 Zob. Smend, Die Weisheit des Jesus Sirach erklärt, 425.

112 Na temat relacji tekstu hebrajskiego do wersji greckiej tego stychu zob. Reiterer, »Urtext« und Übersetzungen, 111-112.

113 Zob. Beentjes, „Ben Sira 44:19-23 - The Patriarchs Text, Tradition, Theology”, 224.

114 Zob. Morla, Los manuscritos hebreos de Ben Sira. Traducción y notas, 287.

11 Zob. Beentjes, ,Ben Sira 44:19-23 - The Patriarchs Text, Tradition, Theology”, 224. Por. Palmisano, Siracide, 420.

116 Zob. Peters, Der jüngst wiederaufgefundene Hebräische Text des Buches Ecclesiasticus, 233. 
Imię 'Jakub' w greckiej wersji dzieła mędrca z Jerozolimy występuje jedenaście razy. Jedynie w analizowanym przez nas tekście (Syr 44,23b) odnosi się ono do osoby patriarchy - syna Izaaka. W pozostałych zaś miejscach, w których ono się pojawia, nie wskazuje tej postaci, lecz cały naród Izraela ${ }^{117}$. Jest to szczególnie widoczne w tych wersetach, które zbudowane są na zasadzie paralelizmu synonimicznego (Syr 24,8; 45,5.17) lub mówią o pokoleniach (Syr 24,23; 36,10; $48,10)$ bądź dziedzictwie Jakuba $(23,12 ; 24,23)$. Potwierdza to również hebrajski tekst Syr 44,23b, w którym zamiast imienia Jakub występuje Izrael (ישראל) Utożsamienie Jakuba z Izraelem opiera się na Rdz 32,29: „Odtąd nie będziesz się zwał Jakub, lecz Izrael, bo walczyłeś z Bogiem i z ludźmi i zwyciężyłeś” ${ }^{119}$.

Księga Rodzaju bardzo dokładnie opisała, w jaki sposób Jakub otrzymał dzięki podstępowi błogosławieństwo swego ojca, a także ostry konflikt Jakuba z jego bratem Ezawem, spowodowany tym oszustwem (kradzieżą) (Rdz 27). Syrach jednak w pochwale Jakuba nie wspomina ani słowem o tych wydarzeniach i ich nie ocenia ${ }^{120}$. Obca jest mu również polemika odnosząca się do tych zdarzeń ${ }^{121}$. Mędrzec skupił się wyłącznie na ich rezultacie, tzn. na przekazaniu błogosławieństwa młodszemu synowi Izaaka ${ }^{122}$. Jego głównym zadaniem jest ukazanie, że przymierze, które Bóg zawarł z Abrahamem i jego potomstwem, jest realizowane i urzeczywistnia się w życiu rodziny ojca dwunastu pokoleń. Syrach nie zajmuje się i nie interesuje się szczegółami, które i tak są oczywiste dla znających dzieje opisane w Rdz. Pragnie on jedynie syntetycznie ukazać rozwój głównych idei teologicznych w narodzie wybranym. B.M. Zapff uważa, że jedną z nich było podkreślenie niezawodności obietnic Bożych ${ }^{123}$. G. Sauer twierdzi zaś, że wiodącym tematem pochwały patriarchów jest przekazanie błogosławieństwa dalszym pokoleniom i dlatego Syrach skupił się wyłącznie na tym zagadnieniu, tak bardzo istotnym dla początków całego narodu Izraela ${ }^{124}$.

W kolejnym stychu pochwały Jakuba (Syr 44,23c) tekst grecki stwierdza, że

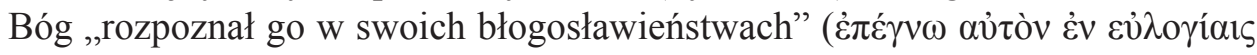

117 Zob. Syr 23,12; 24,8.23; 36,10; 45,5.17; 46,14; 47,22; 48,10; 49,11.

118 Zob. Smend, Die Weisheit des Jesus Sirach erklärt, 425.

119 Zob. Mopsik, La Sagesse de ben Sira, 280.

120 Zob. Schreiner, „Patriarchen im Lob der Väter (zu Sir 44)”, 440.

121 „Die wichtigen Begebenheiten aus dem Leben Jakobs = Israels, seien es die familiären, seien es die religiösen, werden vollkommen übergangen. Wichtig ist dabei die Weitergabe des Segens, der ihm zukam [...]. Die Problematik dieses Geschehens aber interessiert Ben Sira gar nicht" (Sauer, Jesus Sirach/Ben Sira, 305-306).

122 „La «bénédicion» est fondamentalement le rite de transmission du pouvoir du chef de clan patriarcal à son successeur, généralment son fils aîné" (Maertens, L'Éloge des Pères [Ecclesiastique XLIV-L], 62).

123 „Auch die Erwähnung des dritten Patriarchen Israels (Jakob) dient dem Ziel, die Zuverlässigkeit der Verheißungen Gottes herauszustellen" (Zapff, Jesus Sirach 25 - 51, 324).

124 Zob. Sauer, Jesus Sirach/Ben Sira, 306. Por. Maertens, L'Éloge des Pères (Ecclesiastique XLI$V-L), 55.61-62$. 


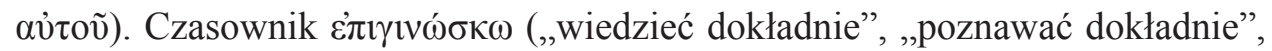
„,rozpoznawać”, „uznawać”, „zaakceptować”) w greckiej wersji Syr występuje czternaście razy. Należy on do pola semantycznego 'poznanie'. Jego podmiotem może być zarówno Bóg $(15,19 ; 18,12$ i 44,23), ale znacznie częściej wyraża on poznanie, którego podmiotem jest człowiek $(9,13 ; 12,12 ; 19,27.29 .29 ; 23,27$; 25,$4 ; 27,27 ; 36,4.4$ i 37,12). Pan poznaje każde dobre dzieło człowieka $(15,19)$ oraz klęskę ludzi $(18,12)$. Każdy zaś powinien rozpoznać zagrożenie swego życia wtedy, gdy zbliża się do ludzi mających władzę zabić innych $(9,13)$. Syr 12,12 jest częścią perykopy, w której mędrzec ostrzega swego ucznia przed fałszywym przyjacielem. W wersecie tym Syrach stwierdza, że gdy ten nieszczery druh odwróci się i stanie się wrogiem, wtedy adept mądrości zrozumie (rozpozna, zaakceptuje) słowa swego mistrza na temat udawanej życzliwości. Człowiek przewrotny ukrywa się i nie chce zostać rozpoznanym $(19,27)$. Każdego poznaje się bowiem ze spojrzenia, a rozumnego z wyrazu twarzy $(19,29)$. Ludzie poznają, że nie ma na świecie nic lepszego od bojaźni Bożej $(23,27)$. Starsi, tzn. przełożeni, powinni umieć rozpoznać zamysł innych $(25,4)$. Ten, kto czyni zło, nie zdoła poznać, skąd ono przyjdzie na niego (27,27). W 36,4 Syrach modli się, prosząc, aby inne narody poznały, tak jak poznał Izrael, że nie ma innego Boga poza JHWH $(36,4)$. Zaś w 37,12 mędrzec wzywa swego ucznia, aby podtrzymywał znajomość z człowiekiem, który został poznany jako ten, kto zachowuje przykazania. Jak

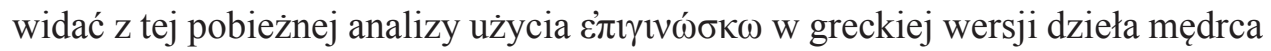
z Jerozolimy, przedmiotem poznania - rozpoznania najczęściej nie są konkretne rzeczy, lecz zachowania ludzi, sytuacja, w której ktoś się znajduje, czy postawa innego człowieka. Bardzo często czasownik ten nie wyraża zwykłego poznania, czyli przejścia ze stanu niewiedzy do wiedzy, lecz odnosi się również do uznania, zaakceptowania poznanej rzeczywistości. Właśnie w takim znaczeniu trzeba odczytać go w Syr 44,23c. Bóg rozpoznał, tzn. zaakceptował, przyjął Jakuba. Autor w tym stychu wyraził się bardzo ogólnie. Nie podał, co zaakceptował w patriarsze. Dzięki temu można odnieść Bożą aprobatę w sposób bardzo szeroki do całości życia i osoby Jakuba. Innymi słowy, Bóg autoryzował go całkowicie we wszystkich jego aspektach i wymiarach. Być może należy w sposób szczególny odnieść tę akceptację do wykradzenia błogosławieństwa i oszukania jego ojca (Izaaka) oraz uznania Jakuba przez niego jako dziedzica (syna pierworodnego). Pomimo że Jakub zdobył uprzywilejowane miejsce w swojej rodzinie nielegalnie, co więcej, dzięki kłamstwu i nieuczciwości - oszustwu, to jednak Bóg uznał prawa, jakie on zdobył i zaakceptował jego czyn z powodu nieodwołalności Bożych obietnic. Uczynił to poprzez błogosławieństwa, których mu udzielił. Trzeba

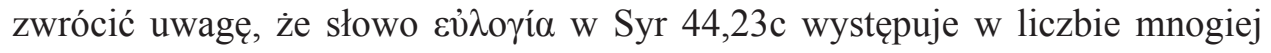

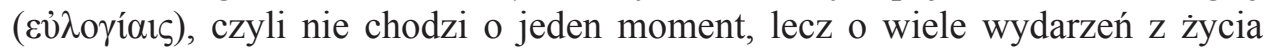
patriarchy, w których zostały mu udzielone poszczególne błogosławieństwa. Być może należy je odnieść do narodzin wielu synów lub też innych zdarzeń, z któ- 
rych wyszedł on zwycięską ręką, pomimo wielkiego zagrożenia (np. spotkanie z Ezawem czy walka z aniołem). Relacja, jaka istnieje pomiędzy rozpoznaniem akceptacją Jakuba ze strony Boga i Jego błogosławieństwami, została wyrażona

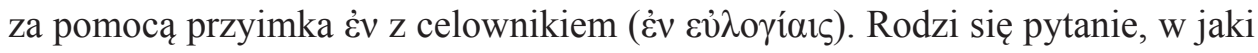
sposób powinna zostać odczytana ta syntagma. Jest to o tyle ważne, że właści-

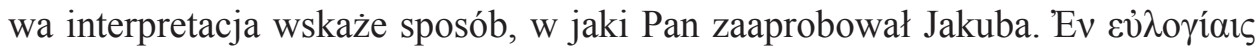
można uznać za dativus loci bądź temporis (,w błogosławieństwach”, tzn. w wydarzeniach lub chwilach, w których Bóg udzielił mu błogosławieństwa), jako dativus causae (,z powodu błogosławieństw”) czy też dativus instrumentalis (,za pomocą - poprzez błogosławieństwa"). Trudno jest jednoznacznie ocenić, która $\mathrm{z}$ tych interpretacji jest najbardziej właściwa i odpowiednia, ponieważ każda bardzo dobrze wpisuje się w kontekst i przesłanie Syr 44,23c. Z całą pewnością można stwierdzić, że aprobata, z jaką spotkał się Jakub ze strony Boga, nie miała jedynie formy intelektualnej zgody i akceptacji, lecz wyraziła się w konkretnych czynach Pana wobec patriarchy oraz darach zarówno duchowych, jak i materialnych, które wyrażały Jego życzliwość wobec niego.

Tekst hebrajski tego stychu jest bardzo podobny w swej wymowie do wersji greckiej Syr 44,23c. Stwierdza bowiem, że Bóg ,umocnił go [Jakuba - przyp. autora] w błogosławieństwie" (ויכוננהו בברכה). Dostrzegalne są dwie różnice pomiędzy wersją oryginalną a tłumaczeniem na język grecki. Po pierwsze, wersja hebrajska nie mówi o akceptacji - uznaniu Jakuba przez Boga, lecz o jego umocnieniu (czasownik כנן w koniugacji Polel) przez Niego. Po wtóre, rzeczownik 'błogosławieństwo' jest w niej w liczbie pojedynczej, a nie mnogiej jak w wersji greckiej. Obie wersje sprawiają zaś tę samą trudność interpretacyjną $\mathrm{w}$ związku z określeniem relacji pomiędzy rozpoznaniem/akceptacją czy umocnieniem a błogosławieństwami czy błogosławieństwem (בברכה

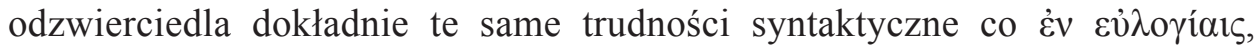
ponieważ ta ostatnia syntagma jest dosłownym tłumaczeniem hebrajskiego pierwowzoru ${ }^{125}$. Zgodnie $\mathrm{z}$ interpretacją tekstu greckiego, która została dokonana powyżej, rozpoznanie (aprobata Jakuba wyraziła się w konkretnych działaniach Boga wobec niego), jest istotowo zbieżne z hebrajskim „umocnił”. Zdaje się, że znacznie ważniejszą różnicą pomiędzy obiema wersjami jest liczba rzeczownika 'błogosławieństwo' (mnoga w tekście greckim i pojedyncza w hebrajskim). Wydaje się, że tłumaczenie wnuka Syracha odnosi się do wielu różnych wydarzeń z życia patriarchy, zaś tekst oryginalny - do jednego konkretnego zdarzenia (najprawdopodobniej do wykradzionego błogosławieństwa jego ojca). Na poprawność dokonanego odczytania Syr 44,23c wskazuje tekst

125 P.C. Beentjes Syr 44,23c thumaczy: ,and He established him with a blessing” (Beentjes, „Ben Sira 44:19-23 - The Patriarchs Text, Tradition, Theology”, 224) sugerując, że błogosławieństwo było narzędziem umocnienia Jakuba (odpowiednik greckiego dativus instrumentalis). 
umieszczony na marginesie manuskryptu B: ,przyznał mu [Bóg - przyp. autora] tytuł pierworodnego" (ויכנהו בבכורה) (por. Rdz 28,13-15; Wj 4,22127). P.C. Beentjes na podstawie powtórzenia w Syr 44,23c słowa 'błogosławieństwo' uważa, że tekst główny manuskryptu B tego stychu jest zwykłym powtórzeniem treści stychu poprzedniego $(44,23 b)$ lub jego streszczeniem. Tekst zaś zapisany na marginesie wprowadza do pochwały Jakuba nowy motyw (pierworództwo), który jest bardzo ważny w całym cyklu o tym patriarsze w Rdz (por. Rdz 25,31-34 i 27,36). Zdaniem holenderskiego badacza, tekst marginalny jest potwierdzony poprzez tekst hebrajski Syr 36,11 (ישראל בכור כיניתה - ,Izrael, któremu przyznałem tytuł "pierworodny"' $)^{128}$. Na tej podstawie stwierdza on, że tekst na marginesie powinien być uznany za bardziej oryginalny i teologicznie bogatszy niż ten zapisany w głównej kolumnie manuskryptu ${ }^{129}$. Opinię tę potwierdzają także T. Maertens ${ }^{130}, \mathrm{~N}$. Peters ${ }^{131}$ oraz w pewnym sensie również V. Morla ${ }^{132}$.

Na podstawie analizy obu wersji Syr 44,23c można powiedzieć, że zarówno hebrajska, jak i grecka wersja tekstu analizowanego stychu są zgodne co do tego, że Bóg przyjął i zaakceptował Jakuba jako kolejnego spadkobiercę obietnic złożonych jego dziadkowi - Abrahamowi. Co więcej, autorytatywnie to potwierdził poprzez swoją łaskawość wobec niego.

Kolejny stych Syr 44,23 nie tylko potwierdza werset 23c, ale również wskazuje na konkretny znak przyjęcia Jakuba jako dziedzica obietnic i zaakceptowania go

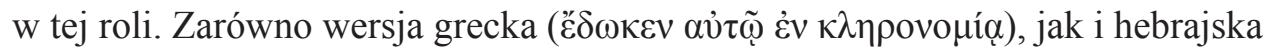
(ויתן לו נחלתו zgodnie stwierdzają ${ }^{134}$, że Bóg dał mu dziedzictwo (tekst hebrajski podkreśla, że chodzi o jego, tzn. Jakuba, dziedzictwo; tekst grecki zawiera zaś

126 ,and He granted him with the title 'firstborn'” (Beentjes, „Ben Sira 44:19-23 - The Patriarchs Text, Tradition, Theology", 224). M.C. Palmisano thumaczy zaś tekst hebrajski w następujący sposób: „Lo acquistò nella primogenitura” (Palmisano, Siracide, 421), C. Mopsik: „Il le définit par l'aînesse” (Mopsik, La Sagesse de ben Sira, 280), zaś V. Morla: „lo estableció en la primogenitura" (Morla, Los manuscritos hebreos de Ben Sira. Traducción y notas, 287).

127 Zob. Mopsik, La Sagesse de ben Sira, 280; Peters, Der jüngst wiederaufgefundene Hebräische Text des Buches Ecclesiasticus, 233-234.

128 R. Smend uważa, że tekst tego wersetu jest korektą Syr 36,11, poprzez Syr 45,2 wpłynął na obecną formę analizowanego przez nas stychu (zob. Smend, Die Weisheit des Jesus Sirach erklärt, 425).

129 Zob. Beentjes, „Ben Sira 44:19-23 - The Patriarchs Text, Tradition, Theology”, 224-225.

130 Zob. Maertens, L'Éloge des Pères (Ecclesiastique XLIV-L), 72-73.

131 Zob. Peters, Der jüngst wiederaufgefundene Hebräische Text des Buches Ecclesiasticus, 234.

132 „La alternativa no es desdeñable, habida cuenta de que el término acaba de ser mencionado y de que, a continuación, se habla de la herencia" (Morla, Los manuscritos hebreos de Ben Sira. Traducción y notas, 287).

133 Dokładnie ten sam tekst odnajdujemy w hebrajskiej wersji w Syr 45,20b w odniesieniu do Aarona (zob. Beentjes, „Ben Sira 44:19-23 - The Patriarchs Text, Tradition, Theology”, 225).

134 „In seltener Einmütigkeit entsprechen sich die Versionen und der B-Text, zu dem nur anzumerken ist" (Reiterer, »Urtext « und Übersetzungen, 115). 
przyimek 'w' [غ̇v], który większość badających ten tekst uważa za dodatek ${ }^{135}$ ). P.C. Beentjes zauważa, że treść tego stychu jest własną interpretacją Syracha cyklu o Jakubie, ponieważ rzeczownik ‘dziedzictwo' nigdy nie został w nim od-

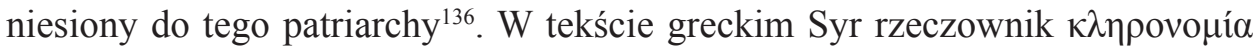
(„dziedziczenie”, „posiadanie”, ,dziedzictwo”, ,,posiadłość”, ,,własność”) ${ }^{137}$ występuje osiemnaście razy. Najczęściej oznacza dziedzictwo, którymi są dobra materialne $(9,6 ; 22,23 ; 33,24 ; 41,6 ; 42,3 ; 45,20.25 a)$. Dwukrotnie odnosi się do części kraju - ziemi, która komuś przypadła jako miejsce zamieszkania $(46,8.9)$ i jeden raz do potomstwa $(44,11)$. Może również wyrażać dziedzictwo, które nie jest materialne, lecz bardziej duchowe: mądrość $(24,20)$ lub Bóg $(45,20)$. Pewną trudność napotykamy z określeniem dziedziczenia, do którego zostało

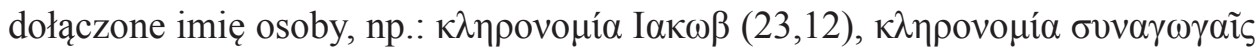
I $\alpha \kappa \omega \beta(24,23)$ czy $\kappa \lambda \eta \rho o v o \mu i ́ \alpha ~ A \alpha \rho \omega v ~(45,25 b)$, ponieważ mogą one odnosić się zarówno do dóbr materialnych (ziemia dana do zamieszkania) jak również duchowych (błogosławieństwo lub przywilej pełnienia służby Bożej w świątyni). Należy zwrócić uwagę na fakt, że grecka wersja Syr dwukrotnie poza 44,23c mówi wprost o dziedzictwie Jakuba $(23,12$ i 24,23$)$. W pierwszym z tych tekstów $\kappa \lambda \eta \rho о v o \mu i ́ \alpha$ I $\alpha \kappa \omega \beta$ oznacza raczej potomków patriarchy, czyli lud Izraela, w drugim zaś $\kappa \lambda \eta \rho о v o \mu i ́ \alpha ~ \sigma v v \alpha \gamma \omega \gamma \alpha i ̄ s ~ I \alpha \kappa \omega \beta$ określa Prawo dane przez Mojżesza, które jest tożsame z Mądrością. W 44,23d mędrzec, mówiąc o tym, że Bóg dał Jakubowi dziedzictwo, odnosi je do ziemi, choć łączy je pośrednio także z potomstwem. Wskazują na to dwa ostatnie stychy, które mówią najpierw o działach - częściach (44,23e), a następnie o pokoleniach - synach Jakuba (44,23f), łącząc je wzajemnie ze sobą. Zdaniem T. Maertensa, Syrach w Syr 44,23d przeciwstawia się współczesnym mu poglądom części środowisk, zwłaszcza tych apokaliptycznych, które głosiły, że dziedzictwem sprawiedliwych będzie Eden, czyli że będzie ono miało wymiar eschatyczny ${ }^{138}$.

Dwa ostatnie stychy tekstu greckiego Syr 44,23 (w. 23ef) należy ująć razem, ponieważ tworzą one pewną logiczną całość i oddzielnie są prawie niezrozu-

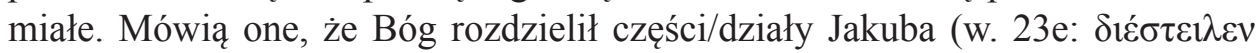

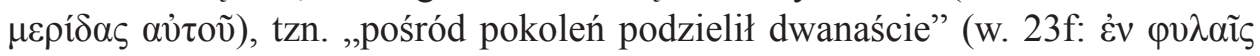

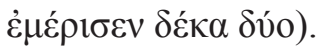

135 V. Morla uważa, że wersja grecka tegoż stychu jest błędna ze względu na obecność w nim przyimka $\dot{\varepsilon} v$ (zob. Morla, Los manuscritos hebreos de Ben Sira. Traducción y notas, 287). Por. Peters, Der jüngst wiederaufgefundene Hebräische Text des Buches Ecclesiasticus, 234; Reiterer, »Urtext« und Übersetzungen, 115; Smend, Die Weisheit des Jesus Sirach erklärt, 425.

136 Zob. Beentjes, „Ben Sira 44:19-23 - The Patriarchs Text, Tradition, Theology”, 225.

137 „Ce terme désigne la propriété, avec la nuance [...], d'une propriété qui vient des ancêtres et présente de ce fait un caractère sacré: c'est la propriété recue, conserve et transmise" (Maertens, L'Éloge des Pères [Ecclesiastique XLIV-L], 65-66).

138 Zob. Maertens, L'Éloge des Pères (Ecclesiastique XLIV-L), 68-69. 
Czasownik $\delta 1 \alpha \sigma \tau \varepsilon ́ \lambda \lambda \omega \mathrm{w}$ stronie czynnej użyty jako przechodni przyjmuje znaczenie: „rozdzielać”, „podzielić”, „określić ściśle”139. W greckiej wersji Syr poza Syr 44,23e występuje jeszcze tylko raz w 16,26. Co więcej, jego dopeł-

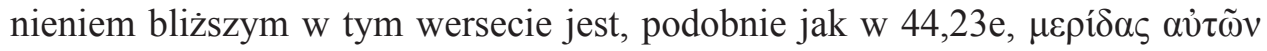
(,działy/role ich”). Syr 16,26 stanowi część opisu stworzenia świata (Syr 16,2430), w którym mędrzec stwierdza, że wszystko powstało na rozkaz Pana i że

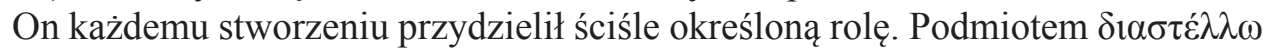
w dziele Syracha jest więc w obu przypadkach Bóg, a czasownik ten wyraża czynność przydzielenia komuś lub czemuś określonej roli lub części. Na tej podstawie można powiedzieć, że w historii Izraela i kształtowania się go jako narodu, Bóg odegrał tę samą rolę co w stworzeniu świata, tzn. wprowadził porządek, ład i harmonię poprzez wyznaczenie i określenie zadań oraz miejsc poszczególnym elementom kosmosu i pokoleniom Izraela.

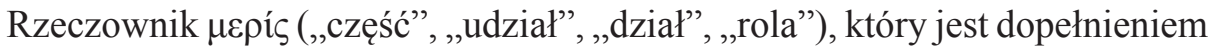
bliższym $\delta \iota \alpha \sigma \tau \varepsilon ́ \lambda \lambda \omega \mathrm{w}$ thumaczeniu na język grecki Syr, poza 44,23e spotykamy jeszcze trzynaście razy. Odnosi się on do części majątku, posiadłości lub dóbr materialnych (Syr 11,18; 14,9; 26,3.3; 41,23). Może oznaczać bliżej nieokreśloną część całości czegoś (Syr 14,14) lub przypisaną komuś spuściznę - dziedzictwo, które niekoniecznie musi być materialne (Syr 7,31; 17,17; 24,12; 45,22.22) ${ }^{140}$. Tylko we wspomnianym powyżej Syr 16,26 słowo to określa rolę, jaką coś lub ktoś spełnia w stworzeniu. Nie zawsze jest łatwo określić, czy analizowany rzeczownik odnosi się do rzeczywistości materialnych, czy też duchowych - niematerialnych. Niekoniecznie muszą one być przeciwstawiane sobie, a wręcz przeciwnie, łączą się nieraz razem, tworząc jedną całość. W Syr 44,23e $\mu \varepsilon \rho i ́ s$ zostało użyte w odniesieniu do dziedzictwa o charakterze materialnym, a ściślej mówiąc, wydaje się, że bezpośrednio do ziemi, którą każde z pokoleń Izraelskich otrzymało po zajęciu Kanaanu (Joz 13,1 - 19,51). Zaskakujące jest to, że Syrach nie przypisał tego czynu (podziału Ziemi Obiecanej po jej zdobyciu) Jozuemu, który według niego wprowadził Izraela do niej i następnie walczył o jej zdobycie (por. Syr 46,1-6). Wydaje się, że grecka wersja Syr zdaje się twierdzić, że jeszcze przed wyjściem z Egiptu i zdobyciem Kanaanu, wtedy, gdy jeszcze żyli synowie Jakuba, Bóg przypisał każdemu z nich część tego kraju, co zostało zrealizowane znacznie później. Syr 44,23e niemalże w sposób proroczy zapowiada wydarzenia przyszłe, które z woli samego Boga miały urzeczywistnić się w przyszłości. W ten sposób autor chciał podkreślić, że dzieje świata i historia Izraela nie są dziełem przypadku, ale rozwijają się według ściśle określonego planu Bożego, który On przypisał każdemu stworzeniu i człowiekowi ${ }^{141}$.

139 Zob. Muraoka, A Greek-English Lexicon of the Septuagint, 159.

140 Zob. Muraoka, A Greek-English Lexicon of the Septuagint, 449.

141 „Il saggio rilegge il passo in cui Giacobbe benedice i suoi dodici figli (cfr. Gen 49), interpretando come agire diretto di Dio che attribuisce un posto preciso a ogni tribù” (Palmisano, Siracide, 421). 
Tekst hebrajski Syr 44,23e jest bardziej zrozumiały i nie sprawia żadnych problemów interpretacyjnych ${ }^{142}$. Mówi, że Bóg umocnił Jakuba w pokoleniach (ויציבהו לשבטים(143). Utwierdzenie patriarchy w jego potomstwie jest więc wypelnieniem się wcześniejszych zapowiedzi, odnoszących się do umocnienia w błogosławieństwie (Syr 44,23c) oraz nadania mu dziedzictwa (Syr 44,23d). Bóg spełnił złożone uprzednio obietnice. Dał Jakubowi liczne potomstwo, któremu zostaną przydzielone konkretne ziemie.

Ostatni stych perykopy poświęconej pochwale Jakuba (Syr 44,23f) w greckiej wersji Syr wyjaśnia, co było podstawą rozdzielenia części/działów, o którym była mowa w Syr 44,23e i dlaczego do niego doszło. Zostały one podzielone przez

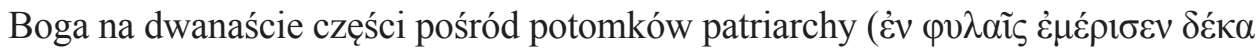

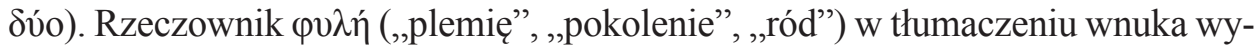
stępuje poza Syr 44,23 jeszcze sześć razy. Tylko w 16,4 odnosi się do nieokreślonego ludu/narodu nieprawych, który zostanie zniszczony. W pozostałych tekstach jednoznacznie jest on odniesiony do pokoleń żydowskich $(36,10 ; 45,6.11 .25$ i 48,10). Dwukrotnie łączy się z imieniem Jakub jako z przydawką w dopełniaczu; w 45,6 i 48,10 mowa jest o pokoleniach Jakuba ( $\varphi$ $\nu \grave{\alpha} \varsigma$ I $\alpha \kappa \omega \beta)$. Liczba mnoga wskazuje, że chodzi w nich o całego Izraela - wszystkie dwanaście pokoleń (Rdz 49,1-28) ${ }^{144}$. Również w 45,11 rzeczownik ten występuje w liczbie mnogiej ( $\varphi v \lambda \tilde{\omega} v$ I $\sigma \rho \alpha \eta \lambda)$ bezpośrednio już w odniesieniu do Narodu Wybranego. Na tej podstawie można stwierdzić, że w greckim tekście Syr $\varphi v \lambda \eta ́$ w liczbie mnogiej odnosi się wyłącznie do Izraela, czyli dwunastu pokoleń pochodzących od synów Jakuba.

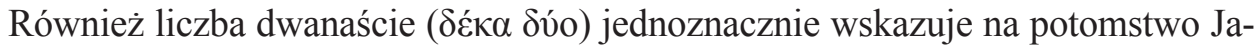
kuba. W całej greckiej wersji dzieła mędrca występuje ona jedynie w Syr 44,23f. Syntagmę غ̇v pviaĩs można zinterpretować na dwa sposoby. Po pierwsze, jako dativus loci („wśród pokoleń”, „pośród pokoleń” , „w pokoleniach”), po wtóre, jako dativus causae (,z powodu pokoleń”). Obie interpretacje doskonale wpisują się w kontekst i trudno jest jednoznacznie wskazać, która z nich jest bardziej właściwa.

Bóg działy/części, o których mówił Syr 44,23e, podzielił pomiędzy dwana-

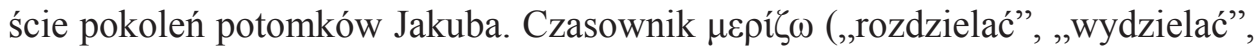

142 P.C. Beentjes wręcz przeciwnie twierdzi, że hebrajski tekst Syr 44,23 ef jest trudniejszy do zrozumienia niż jego wersja grecka czy syryjska (zob. Beentjes, „Ben Sira 44:19-23 - The Patriarchs Text, Tradition, Theology", 214).

143 Na temat tekstu hebrajskiego tego stychu zob. Morla, Los manuscritos hebreos de Ben Sira. Traducción y notas, 287.

144 Zob. Maertens, L'Éloge des Pères (Ecclesiastique XLIV-L), 69-72; Mopsik, La Sagesse de ben Sira, 281; T. Rash Brown, Sinners, Idol-Worshippers and Fools among the Men of Hesed: Ben Sira's Pedagogy in Praise of the Fathers (Sir 44-50) (niepublikowany doktorat obroniony na Berkeley University w 1998) 68; Skehan - Di Lella, The Wisdom of Ben Sira, 505; Smend, Die Weisheit des Jesus Sirach erklärt, 425-426; Snaith, Ecclesiasticus or The Wisdom of Jesus Son of Sirach, 219; Zapff, Jesus Sirach 25 - 51, 324. 


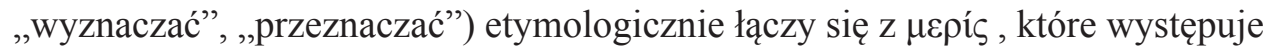
$\mathrm{w}$ poprzednim stychu. Oba te słowa wywodzą się od wspólnego rdzenia $\mu \varepsilon \rho$, który zawiera w sobie sens 'część' ${ }^{145}$ i należą do pola semantycznego 'dziedzictwo'. Tekst grecki podkreśla poprzez użycie $\mu \varepsilon p i \zeta \zeta$, że działy, które otrzymały pokolenia Izraela - potomkowie synów Jakuba, są ich dziedzictwem nadanym przez Boga, które On im ofiarował jako wypełnienie wcześniejszych zapowiedzi złożonych Abrahamowi i przekazanych im przez Izaaka i ich ojca Jakuba. W synach tego ostatniego patriarchy można dostrzec początek realizacji zapowiedzi licznego potomstwa, którą otrzymał ojciec Izraela w Syr 44,21c.

Tekst hebrajski ostatniego stychu pochwały Jakuba jest prawie identyczny $\mathrm{z}$ thumaczeniem greckim. Podaje on jednak cel umocnienia Jakuba w jego pokoleniach. Był nim podział na dwanaście (לחלק שנים עשר ${ }^{146}$ לח dwóch ostatnich stychów perykopy poświęconej Jakubowi skupia się na potomstwie patriarchy, grecki zaś mówi o jego synach, ale również pośrednio o ich dziedzictwie - ziemi. P.C. Beentjes uważa, że hebrajski tekst Syr 44,23ef jest przepracowaniem Pwt 32,8-9. Swoją tezę uzasadnia występowaniem aż sześciu tych samych słów (נחל, נחלח, חלק, נצב, עליון, כון) w obu tekstach ${ }^{147}$. Jego opinię potwierdza R.C.T. Hayward ${ }^{148}$.

Podsumowując pochwałę Jakuba zawartą w Syr 44,23, należy zwrócić uwagę, że mędrzec, podobnie jak w przypadku poprzednich patriarchów (Abrahama i Izaaka), pominął zupełnym milczeniem trudności, z jakimi zmagał się on podczas swego życia. Nie mówi nic o konflikcie z jego bratem Ezawem oraz długim procesie pojednania pomiędzy nimi ${ }^{149}$. Syrach wybrał z ogromną roztropnością jedynie te tematy, które ukazują Jakuba jako nienagannego w burzliwych losach jego życia oraz jako osobę wolną od wszelkiego rodzaju oskarżeń ${ }^{150}$. Jest

Zob. R. Romizi, Greco antico. Vocabolario greco italiano etimologico e ragionato (Bologna: Zanichelli $\left.{ }^{3} 2007\right) 797$.

146 Na temat hebrajskiego tekstu tego stychu zob. Peters, Der jüngst wiederaufgefundene Hebräische Text des Buches Ecclesiasticus, 234.

147 Zob. Beentjes, „Ben Sira 44:19-23 - The Patriarchs Text, Tradition, Theology”, 225.

148 Zob. R.T.C. Hayward, „El Elyon and the Divine Names in Ben Sira”, Ben Sira's God. Proceedings of the International Ben Sira Conference Durham - Ushaw College 2001 (ed. R. Egger-Wenzel) (BZAW 321; Berlin: de Gruyter 2002) 189.

149 Zob. Lee, Studies in the Form of Sir 44 - 50, 207; Sauer, Jesus Sirach/Ben Sira, 305-306.

150 „Egli [Syrach - przyp. autora] parla della benedizione che Dio pose sul capo di Giacobbe e dell'azione di Dio nella sua vita e nelle sue scelte. Con ciò Ben Sirac evidenzia a chiare lettere nelle vicende laiche, umane, anzi spesso troppo 'umane' di Giacobbe, l'azione di Dio. Però si tratta di una lettura ambigua, positiva e negativa a un tempo. Positiva perché non isola il sacro separadnolo dal profano. Ben Sirac infatti non sceglie le pagine 'teologiche' della Genesi, cioè quelle in cui Giacobbe incontra Dio. Al contrario pensa che la vita stessadi Giacobbe, proprio nel suo aspetto più laico e profano, sia lo spazio dell/incontro con Dio, sia il momento in cui Dio fa riposare su di lui la sua benedizione. Ma in una simile lettura c'è anche il negativo: il pericolo di mistificare il tutto. Il fatto che Giacobbe sia considerato primogenito viene visto come il risultato dell'agire di Dio, come effetto della benedizione di Dio (44,23b), non come un atto di rivalità 
on wybrańcem Boga, na którego przechodzą obietnice oraz przymierze zawarte z Abrahamem i przekazane mu przez jego ojca Izaaka, których z kolei udziela swoim dwunastu synom, czyli całemu Izraelowi ${ }^{151}$.

\section{Zakończenie}

Syrach w swojej pochwale Izaaka i Jakuba oparł się wyłącznie na tekście Księgi Rodzaju i na jej podstawie przedstawił ich (nie zaczerpnął z żadnej idei teologicznej, którą tym dwóm patriarchom przypisała tradycja czasów Drugiej Świątyni ${ }^{152}$ ). Prezentacji ich postaci nie dokonał jednak na podstawie zwykłego podsumowania cyklów im poświęconych czy też syntetycznego przedstawienia ich życia i dzieł, których dokonali, lecz w sposób bardzo kreatywny i pobudzający do dalszej refleksji zaprezentował własną, oryginalną relekturę życia i działalności tych dwóch patriarchów ${ }^{153}$. T. Maertens stwierdza, że Syrach nie zamierzał napisać streszczenia historii ani Izaaka, ani Jakuba, lecz przedstawił czytelnikowi istotę przesłania teologicznego, które było związane $\mathrm{z}$ tymi postaciami $\mathrm{i}^{154}$.

W Syr 44,22-23 mędrzec mówi przede wszystkim o działaniu Boga w życiu Izaaka i Jakuba. Ukazuje ich jedynie jako osoby, które są przedmiotem tego działania, w przeciwieństwie do Abrahama, któremu w pochwale dedykowanej temu patriarsze mędrzec przypisał ważne czyny (zachowywanie Prawa, trwanie w przymierzu i wierność w próbie; zob. Syr 44,20 ${ }^{155}$. Potomkowie praojca Izraela są jedynie spadkobiercami, nośnikami i przekazicielami z kolei ich potomstwu obietnic i przymierza, jakie Bóg zawarł z Abrahamem ${ }^{156}$. Należy podkreślić, że w Jakubie i jego potomstwie zapowiedzi te zaczynają się konkretnie i materialnie realizować.

del fratello minore, come un attentato di Giacobbe nei confronti di Esaù" (Petraglio, Il libro che contamina le mani, 86-87).

151 „Jakob hat im Grunde nach Ben Sira nur die Aufgabe, auf Israel überzuleiten und den Bund mit Jahwe dem Volk weiterzugeben” (Schreiner, „Patriarchen im Lob der Väter [zu Sir 44]”, 440). Por. Palmisano, Siracide, 420; Sauer, Jesus Sirach/Ben Sira, 306.

152 Zob. D.S. Russell, The Old Testament Pseudepigrapha. Patriarchs \& Prophets in Early Judaism (Philadelphia: SCM 1987) 79-84.

153 Zob. Beentjes, „Ben Sira 44:19-23 - The Patriarchs Text, Tradition, Theology”, 226. Por. Maertens, L'Éloge des Pères (Ecclesiastique XLIV-L), 75.

154 „On notera que l'éloge des patriarches qui suivent immédiatement Abrahamne sélectionne aucun fait particulier de leur vie; Ben Sira se borne à rappeler des événements très généraux. Il ne s'agit pas d'un résumé historique, mais d'un sommaire théologique" (Maertens, L'Éloge des Pères [Ecclesiastique XLIV-L], 56).

155 „Come nel caso della descrizione di Isacco, anche in quella di Giacobbe Ben Sira pone al centro l'agire di Dio" (Palmisano, Siracide, 420).

156 „Isacco e Giacobbe sono descritti piuttosto come prosecutori passivi di quanto è iniziato con Abramo, ovvero in loro appare in tutto il suo splendore l'agire di Dio. Attraverso Isacco, Dio diede stabilità alla discendenza di Abramo e attraverso Giacobbe la benedizione si concretizza nel possesso della terra promessa alle dodici tribù" (Palmisano, Siracide, 421). Por. Mack, Wis- 


\section{Bibliografia:}

Asurmendi J., „El elogio de los antepasados (Sir 44-50): haciendo historia...”, Reseña Biblica 41 (2004) 45-51.

Balembo B., „Benedizione”, Temi teologici della Bibba (ed. R. Penna - G. Perego - G. Ravasi) (Dizionari San Paolo; Cinisallo Balsamo: San Paolo 2010) 133-140.

Barton J., „Izaak”, Stownik wiedzy biblijnej (red. B.M. Metzger - M.D. Coogan) (Warszawa: Vocatio 1996) 244-245.

Beentjes P.C., „Ben Sira 44:19-23 - The Patriarchs Text, Tradition, Theology”, Studies in the Book of Ben Sira. Papers of the Third International Conference on the Deuterocanonical Books, Shime'on Centre, Pápa, Hungary, 18-20 May, 2006 (red. G.G. Xeravits - J. Zsengellér) (Supplements to the Journal for the Study of Judaism 127; Leiden - London: Brill 2008) 209-228.

Beentjes P.C., The Book of Ben Sira in Hebrew. A Text Edition of all Extant Hebrew Manuscripts and a Synopsis of all Parallel Hebrew Ben Sira Texts (Supplements to Vetus Testamentum LXVIII; Leiden - New York - Köln: E.J. Brill 1997).

Blass F. - Debruner A., Grammatica del greco del Nuovo Testamento (Introduzione allo Studio della Bibbia. Supplementi 2; Brescia: Paideia ${ }^{2}$ 1997).

Boccaccio P. - Bernardi G., Ecclesiasticus. Textus hebraeus secundum fragmenta reperta (Roma: Editrice PIB 1986).

Bonora A., „Siracide”, Libri sapienziali e altri scritti (red. A. Bonora - M. Priotto ed altri) (Logos. Coso di Studii Biblici 4; Torino: Elle Di Ci 1997) 85-98.

Bonora A., Siracide. Le radici nella tradizione (Leggere oggi la Bibbia 1.17; Brescia: Queriniana 1988).

The Book of Ben Sira. Text, Concordance and an Analysis of the Vocabulary (The Historical Dictionary of the Hebrew Language; Jerusalem: The Academy of the Hebrew Language and the Shrine of the Book 1973).

Bosak P.C., Stownik - konkordancja osób Nowego Testamentu (Poznań: W drodze 1991).

Brown, Sinners, Idol-Worshippers and Fools among the Men of Hesed: Ben Sira's Pedagogy in Praise of the Fathers (Sir 44-50), 67-69; Schreiner, „Patriarchen im Lob der Väter (zu Sir 44)”, 440.

Calduch-Benages N., „The Absence of Named Women from Ben Sira's Praise of Ancestors”, Rewriting Biblical History. Essays on Chronicles and Ben Sira in Honor of Pancratius C. Beentjes (red. J. Corley - H. van Grol) (Deuterocanonical and Cognate Literature Studies 7; Berlin - New York: de Gruyter 2011) 301-318.

Calduch-Benages N. - Ferrer J. - Liesen J., La Sabiduría del escriba. Wisdom of the Scribe (Bibioteca Midrásica 26; Estella: Editorial Verbo Divino 2003).

Clifford R.J., The Wisdom Literature (Interpreting Biblical Texts; Nashville: Abingdon 1998).

Coggins R.J., Sirach (Guides to Apocrypha and Pseudepigrapha; Sheffield: Sheffield Academic Press 1998).

dom and the Hebrew Epic. Ben Sira's Hymn in Praise of the Fathers, 27.45; Maertens, L'Éloge des Pères (Ecclesiastique XLIV-L), 55; Petraglio, Il libro che contamina le mani, 91.93; Rash Brown, Sinners, Idol-Worshippers and Fools among the Men of Hesed: Ben Sira's Pedagogy in Praise of the Fathers (Sir 44-50), 67-69; Schreiner, „Patriarchen im Lob der Väter (zu Sir 44)", 440. 
Corley J., „A Numerical Structure in Sirach 44:1 - 50:24”, CBQ 1 (2007) 43-63.

Corley J., „Seeds of Messianism in Hebrew Ben Sira and Greek Sirach”, The Septuagint and Messianism (ed. M.A. Knibb) (BEThL CXCV; Leuven - Paris: Leuven University Press - Uitgeverij Peeters 2006) 301-312.

Corley J., „Sirach 44:1-15 as Introduction to the Praise of the Ancestors”, Study in the Book of Ben Sira. Papers of the Third International Conference on the Deuterocanonical Books, Shime'on Centre, Pápa, Hungary, 18-20 May, 2006 (red. G.G. Xeravits - J. Zsengellér) (Supplements to the Journal for the Study of Judaism 127; Leiden - London: Brill 2008) 151-181.

Crenshaw J.L., Old Testament Wisdom. An Introduction (Louisville: Westminster John Knox Press $\left.{ }^{2} 1998\right)$.

Crenshaw J.L., „The Book of Sirach. Introduction, Commentary, and Reflections”, The New Interpreter's Bible. V: Introduction to Wisdom Literature; Proverbs; Ecclesiastes; Song of Songs; Book of Wisdom; Sirach (Nashville: Abingdon 1997) 601-867.

Di Lella A.A, „Ben Sira's Praise of the Ancestors of Old (Sir 44-49): The History of Israel as Parenetic Apologetics", History and identity: how Israel's authors viewed its earlier history (red. N. Calduch-Benages - J. Liesen) (International Society for the Study of Deuterocanonical and Cognate Literature. International Conference; Berlin - New York: de Gruyter 2006) 151-170.

Di Lella A.A., „Wisdom of Ben Sira”, The Anchor Bible Dictionary (red. D.N. Freedman) (New York - London - Toronto: Doubleday 1992) VI, 931-945.

Gilbert M., Le cinq livres des Sages (Lire la Bible 129; Paris: Cerf 2003).

Gilbert M., Ben Sira. Recueil d'études - Collected Essays (BEThL 264; Leuven - Paris - Walpole: Uitgeverij Peeters 2014) 331-345.

Goshen-Gottstein A., „Ben Sira's Praise of the Fathers: A Canon-Conscious Reading”, Ben Sira's God. Proceedings of the International Ben Sira Conference Durham - Ushaw College 2001 (red.

R. Egger-Wenzel) (BZAW 321; Berlin - New York: de Gruyter 2002) 235-267.

A Greek-English Lexicon of the New Testament and Other Early Christian Literature (Chicago London: The University of Chicago Press ${ }^{2} 1979$ ).

Gregory B.G., „Abraham as the Jewish Ideal: Exegetical Traditions in Sirach 44:19-21”, CBQ 1 (2008) 66-81.

Guillet J., „Błogosławieństwo”, Stownik teologii biblijnej (red. X. Leon-Dufour) (Poznań: Pallottinum 1990) 78-85.

Hayward R.C.T., „El Elyon and the Divine Names in Ben Sira”, Ben Sira's God. Proceedings of the International Ben Sira Conference Durham - Ushaw College 2001 (ed. R. Egger-Wenzel) (BZAW 321; Berlin: de Gruyter 2002) 180-198.

von Höffken P., „Warum schwieg Jesus Sirach über Esra?”, ZAW 87 (1975) 184-202.

Jansen E., Das Gottesvolk und seine Geschichte. Geschichtsbild und Selbstverständnis im palästinensischen Schriftum von Jesus Sirach bis Jehuda ha-Nasi (Neukirchen: Neukirchener Verlag 1971).

Kowalik K.P., „Postać Abrahama w świetle Księgi Syracha”, Przeznaczyteś nas dla Twojej prawdy (4Q 495). Studia dla Dr. Zdzisława J. Kapery w 65. rocznice urodzin (red. W. Chrostowski) (Rozprawy i Studia Biblijne 29; Warszawa: Vocatio 2007) 421-431.

Kraus W. - Karrer M. (red.), Septuaginta Deutsch. Das griechische Alte Testament in deutscher Übersetzung (Stuttgart: Deutsche Bibelgesellschaft 2009). 
Księgi greckie. Przekład interlinearny z kodami gramatycznymi i indeksem form podstawowych (tłum. M. Wojciechowski) (Prymasowska Seria Biblijna; Warszawa: Vocatio 2008).

Lee T.R., Studies in the Form of Sir 44 - 50 (SBLDS 75; Atlanta: Scholars Press 1986).

Lévi I., The Hebrew Text of the Book of Ecclesiasticus (Semmitic Study Series; Leiden: Brill 1904).

Lust J. - Eynikel E. - Hauspie K., A Greek - English Lexicon oft he Septuagint (Stuttgart: Deutsche Bibelgesellschaft 1992) I-II.

Lutter A.B. - Klouda S.L., „Isaac”, Dictionary of the Old Testament: Pentateuch (ed. T.D. Alexander - D.W. Baker) (Illinois - Leicester: InterVarsity Press 2003) 445-450.

Mack B.L., Wisdom and the Hebrew Epic. Ben Sira's Hymn in Praise of the Fathers (Chicago - London: The University of Chicago Press 1985).

MacKenzie R.A.F., „Ben Sira as Historian”, Trinification of the World: A Festschrift in Honor of F.E. Crowe (red. T.A. Dunne - J.M. Laport) (Toronto: Regis College Press 1978) 312-327.

Maertens T., L'Éloge des Pères (Ecclesiastique XLIV-L) (Lumiere et Vie 5; Bruges: Editions de l'Abbaye de Saint-Andre 1956).

Marböck J., „Die «Geschichte Israels» als 'Bundesgeschichte' nach dem Sirachbuch”, Der neue Bund im alten. Studien zur Bundestheologie der beiden Testamente (red. E. Zenger) (Quaestiones Disputate 146; Freiburg - Basel - Wien: Herder 1993) 177-197.

Marböck J., „Il libro del Siracide”, Introduzione all'Antico Testamento (red. E. Zenger) (Brescia: Queriniana 2005) 616-629.

Martin J.D., „Ben Sira's Hymn to the Fathers: A Messianic Perspective”, Crises and Perspectives (ed. A.S. van der Woude) (Oudtestamentische Studiën 24; Leiden: Brill 1986) 107-123.

Martin-Achard R., „Isaac”, The Anchor Bible Dictionary (ed. D.N. Freedman) (New York - London - Toronto: Doubleday 1992) III, 462-470.

Minissale A., Siracide (Ecclesiastico) (Nuovissima Versione della Bibbia 23; Cinisello Balsamo: San Paolo 1989).

Mopsik C., La Sagesse de ben Sira (Les Dix Paroles; Paris: Verdier 2003).

Morla V., Los manuscritos hebreos de Ben Sira. Traducción y notas (Asociación Bíblica Española 59; Estella: Editorial Verbo Divino 2012).

Morla Asensio V., Libri sapienziali e altri scritti (Introduzione allo studio della Bibbia 5; Brescia: Paideia 1997).

Mulder O., Simon the High Priest in Sirach 50 (Supplements to the Journal for the Study of Judaism 78; Leiden-Boston: Brill 2003).

Mulder O., „Two Approaches: Simon the High Priest and YHWH God of Israel/God of All in Sirach 50", Ben Sira's God. Proceedings of the International Ben Sira Conference Durham - Ushaw College 2001 (red. O. Kaiser) (BZAW 321; Berlin-New York: de Gruyter 2002) 221-234.

Muraoka T., A Greek-English Lexicon of the Septuagint (Louvain - Paris - Walpole: Peeters 2009).

Murphy R.E., L'albero della vita. Una esplorazione della letteratura sapienziale biblica (Biblioteca biblica 13; Brescia: Queriniana ${ }^{2} 2000$ ).

Niccacci A., „La Lode dei Padri: Ben Sira tra passato e futuro”, Initium sapientiae. Scritti in onore di Franco Festorazzi nel suo $70^{\circ}$ compleanno (red. R. Fabris) (Supplementi alla «Rivista Biblica» 36; Bologna: EDB 2000) 199-225.

Obermayer H. - Speidel K. - Vogt K. - Zieler G. (ed.), Piccolo dizionario biblico (Cinisello Balsamo: San Paolo 1988). 
Palmisano M.C., Siracide. Introduzione, traduzione e commento (Nuova versione della Bibbia dai testi antichi 34; Cinisello Balsamo: San Paolo 2016).

Pazera W., „Pochwała ojców w księdze Jezusa Syracha”, Częstochowskie Studia Teologiczne 14 (1986) 271-308.

Penar T., Nortwest Semitic Philology and the Hebrew Fragments of Ben Sira (BibOr 28; Rome: Biblical Institute Press 1975).

Pérez Rodríguez G., „Eclesiástico”, Biblia Comentada IV. Libros Sapienciales (Biblioteca de Autores Cristianos 218; Madrid: La Editorial Catolica $\left.{ }^{2} 1967\right)$ 1072-1307.

Peters N., Das Buch Jesus Sirach oder Ecclesiasticus (Exegetisches Handbuch zum Alten Testament 25; Münster: Aschendorff 1913).

Peters N., Der jüngst wiederaufgefundene Hebräische Text des Buches Ecclesiasticus (Freiburg im Breisgau: Herdersche Verlagschandlung 1902).

Petraglio R., Il libro che contamina le mani. Ben Sirac relegge il libro e la storia d'Israele (Teologia IV; Palermo: Edizioni Agustinus 1993).

Phua M., „Sirach, Book of”, Dictionary of the Old Testament. Wisdom, Poetry \& Writings (red. T. Longman III - P. Enns) (Downers Grove - Nottingham: IVP Academic - Inter-Varsity Press 2008) 720-728.

Pietersma A. - Wright B.G. (red.), A New English Translation of the Septuagint. And the Other Greek Translations Traditionally Included under that Title (New York - Oxford: Oxford University Press, 2007).

Pinto S., I segreti della Sapienza. Introduzione ai Libri sapienziali e poetici (Cinisello Balsamo: San Paolo 2013).

Piwowar A., „Dlaczego Syrach pominął Ezdrasza w Pochwale Ojców (Syr 44 - 50)?”, The Biblical Annals 1/58 (2011) 105-131.

Piwowar A., Greka Nowego Testamentu. Gramatyka (Biblioteka 'Verbum Vitae' 1; Kielce: Verbum 2010).

Piwowar A., „Syrach - obrońca prawowitego arcykapłana”, Od Melchizedeka do Jezusa - Arcykapłana (red. D. Dziadosz) (Analecta Biblica Lublinensia 5; Lublin: Wydawnictwo KUL 2010) 93-117.

Popowski R., Wielki stownik grecko-polski Nowego Testamentu. Wydanie z petna lokalizacja greckich haset, kluczem polsko-greckim oraz indeksem form czasownikowych (Prymasowska Seria Biblijna; Warszawa: Vocatio ${ }^{4} 2006$ ).

Potocki S., „Księgi mądrościowe”, Wstęp do Starego Testamentu (red. S. Łach) (Wstęp do Pisma Świętego 2; Poznań - Warszawa: Pallottinum 1973) 631-751.

Potocki S., „Mądrość uczonego w Piśmie (Księga Syracha)”, Mądrość starotestamentowego Izraela (red. S. Potocki i in.) (Wprowadzenie w Myśl i Wezwanie Ksiąg Biblijnych 6; Warszawa: Wydawnictwo ATK 1999) 161-204.

Pudełko J.J., „Dlaczego Adam zamyka Pochwałe Ojców (Syr 44 - 49)”, The Biblical Annals $7 / 4$ (2017) 441-457.

Pudełko J.J., „(Nie)obecność kobiet w Pochwale ojców (Syr 44 - 49)”, 'Niewiastę dzielna kto znajdzie?' (Prz 31,10). Rola kobiet w biblijnej historii zbawienia (red. A. Kubiś - K. Napora) (Analecta Biblica Lublinensia; Lublin: Wydawnictwo KUL 2016) 195-210.

Rahlfs A. (red.), Septuaginta. Id est Vetus Testamentum graece iuxta LXX interpretes I-II (Stuttgart: Deutsche Bibelgesellschaft 1979). 
Rash Brown T., Sinners, Idol-Worshippers and Fools among the Men of Hesed: Ben Sira's Pedagogy in Praise of the Fathers (Sir 44-50) (niepublikowany doktorat obroniony na Berkeley University w 1998). Reiterer F.V., "Urtext« und Übersetzungen. Sprachstudie über Sir 44,16 - 45,26 als Beitrag zur Siraforschung (Münchener Universitätsschriften 12; St. Ottilien: EOS Verlag St. Ottilien 1980).

Reiterer F.V., Zählsynopse zum Buch Ben Sira (Fontes et Subsidia ad Bibliam Pertinentes 1; Berlin - New York: de Gruyter 2003).

Richards K.H., „Bless/blessing”, The Anchor Bible Dictionary (ed. D.N. Freedman) (New York London - Toronto: Doubleday 1992) I, 753-755.

Romizi R., Greco antico. Vocabolario greco italiano etimologico e ragionato (Bologna: Zanichelli $\left.{ }^{3} 2007\right)$.

Russell D.S., The Old Testament Pseudepigrapha. Patriarchs \& Prophets in Early Judaism (Philadelphia: SCM 1987).

Ryken L. - Wilhoit J.C. - Longman III T., Le immagini bibliche. Simboli, figure retoriche e temi letterari della Bibbia (Dizionari San Paolo; Cinisello Balsamo: San Paolo 2006).

Sauer G., Jesus Sirach/Ben Sira (Das Alte Testament Deutsch. Apokryphen 1; Göttingen: Vandenhoeck \& Ruprecht 2000).

Sauer G., Studien zu Ben Sira (BZAW 440; Berlin - Boston: de Gruyter 2013).

Scalabrini P.R., „La galleria degli antenati (Sir 44-50)”, Libri sapienziali (red. A. Priotto) (Parole di Vita 8; Padova: Messaggero di Sant'Antonio 2015) 315-323.

Schreiner J., „Patriarchen im Lob der Väter (zu Sir 44)”, Textarbeit: Studien zu Texten und ihrer Rezeption aus dem Alten Testament und der Umwelt Israels (FS P. Weimar) (red. K. Kiesow T. Meurer) (AOAT 294; Münster: Ugarit-Verlag 2003) 425-441.

Septuaginta czyli Biblia Starego Testamentu wraz z księgami deuterokanonicznymi i apokryfami (thum. R. Popowski) (Prymasowska Seria Biblijna; Warszawa: Vocatio 2013).

Septuaginta dutsch. Das griechische Alte Testament in deutscher Übersetzung (ed. W. Kraus M. Karrer) (Stuttgart: Deutsche Bibelgesellschaft 2009).

Ska J.L., „L'éloge des pères dans le Siracide (Si 44-50) et le canon de l'Ancien Testament”, Treasures of wisdom: studies in Ben Sira and the book of Wisdom (FS M. Gilbert) (red. N. Calduch-Benages - J. Vermeylen) (BEThL 143; Leuven: Leuven University Press 1999) 181-193.

Skehan P.W. - Di Lella A.A., The Wisdom of Ben Sira (The Anchor Bible 39; New York - London Toronto: Doubleday 1987).

Smend R., Die Weisheit des Jesus Sirach erklärt (Berlin: Verlag von Georg Reimer 1906).

Smend R., Die Weisheit des Jesus Sirach hebräisch und deutsch (Berlin: Verlag von Georg Reimer 1906).

Snaith J.G., Ecclesiasticus or The Wisdom of Jesus Son of Sirach (The Cambridge Bible Commentary; Cambridge: Cambridge University Press 1974).

Synowiec J.S., Mędrcy Izraela, ich pisma i nauka (Kraków: Bratni Zew 21997).

Unterman J., „Izaak”, Encyklopedia biblijna (red. P.J. Achtemeier) (Warszawa: Vocatio - Adam 1999) 415-417.

Vell a J., „Ecl esiast ico”, La Sagrada Escritura. Texto y comentario. Antiguo Testamento. V: Eclesiástico, Isaía, Jeremías, Ezequiel (red. A.T. Fernández) (Madrid: La Editorial Catolica, S.A. 1970) 3-218. 
Wright III B.G., „Eschatology without a Messiah in the Wisdom of Ben Sira”, The Septuagint and Messianism (ed. M.A. Knibb) (BEThL CXCV; Leuven - Paris: Leuven University Press - Uitgeverij Peeters 2006) 313-323.

Wrigdht III B.G., ,The Use and Interpretation of Biblical Tradition in Ben Sira's Praise of the Ancestors", Study in the Book of Ben Sira. Papers of the Third International Conference on the Deuterocanonical Books, Shime'on Centre, Pápa, Hungary, 18-20 May, 2006 (red. G.G. Xeravits - J. Zsengellér) (Supplements to the Journal for the Study of Judaism 127; Leiden - London: Brill 2008) 183-207.

Whybray R.N., „Ben Sira and History”, Treasures of wisdom: studies in Ben Sira and the book of Wisdom (FS M. Gilbert) (red. N. Calduch-Benages - J. Vermeylen) (BEThL 143; Leuven: Leuven University Press 1999) 137-145.

Wypych S., Pięcioksiag (Wprowadzenie w Myśl i Wezwanie Ksiąg Biblijnych 1; Warszawa: Akademia Teologii Katolickiej 1987).

Zapff B.M., Jesus Sirach 25 - 51 (Die Neue Echter Bibel. Altes Testament: Würzburg: Echter 2010). Ziegler J., Sapientia Iesu Filii Sirach (Septuaginta. Vetus Testamentum Graecum Auctoritate Academiae Scientiarum Gotteingensis editum XII/2; Göttingen: Vandenhoeck\&Ruprecht ${ }^{2} 1980$ ).

http://bensira.org/navigator.php?Manuscript=B\&PageNum=27 [dostęp: 20.05.2018]. 
